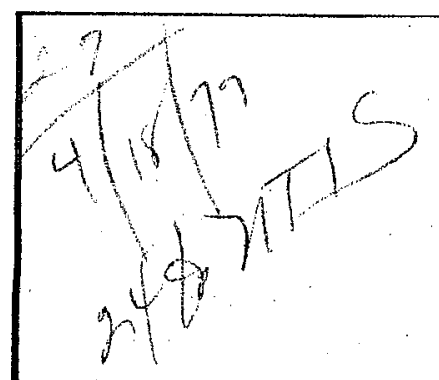

$\frac{\text { PNL-2690 }}{\text { UC-70 }}$

\title{
Conceptual Design of a Nuclear Waste Vitrification Facility
}
D. E. Larson
M. S. Hanson
H. T. Blair
L. S. Romero
W. F. Bonner
D. H. Siemens
A. A. Garrett

May 1978

Prepared for the U.S. Department of Energy under Contract EY-76-C-06-1830

Pacific Northwest Laboratory Operated for the U.S. Department of Energy by Battelle Memorial Institute 
NOTICE

This report was prepared as an account of work sponsored by the United States Government. Neither the United States nor the Department of Energy, nor any of their employees, nor any of their contractors, subcontractors, or their employees, makes any warranty, express or implied, or assumes any legal liability or responsibility for the accuracy, completeness or usefulness of any information, apparatus, product or process disclosed, or represents that its use would not infringe privately owned rights.

The views, opinions and conclusions contained in this report are those of the contractor and do not necessarily represent those of the United States Government or the United States Department of Energy.

\author{
PACIFIC NORTHWIEST LABORATORY \\ operated by \\ BATTELLE \\ for the \\ UNITED STATES DEPARTMENT OF ENERGY \\ Under Contract EY-76-C-06-1830
}

\author{
Printed in the United States of America \\ Available from \\ National Technical information Service \\ United States Department of Commerce \\ 5285 Port Royal Road \\ Springfield, Virginia 22757 \\ Price: Printed Copy $\$$; Microfiche $\$ 3.00$ \\ NTIS \\ *Pages Selling Price \\ $001-025 \quad \$ 4.50$ \\ 026-050 $\$ \$ 5.00$ \\ $051-075 \quad \$ 5.50$ \\ 076-100 $\$ 6.00$ \\ $101.125 \quad \$ 6.50$ \\ $126-150 \quad \$ 7.00$ \\ $151-175 \quad \$ 7.75$ \\ 176-200 $\$ 8.50$ \\ $201-225 \quad \$ 8.75$ \\ 226-250 \$9.00 \\ $251-275 \quad \$ 10.00$ \\ $276-300 \quad \$ 10.25$
}




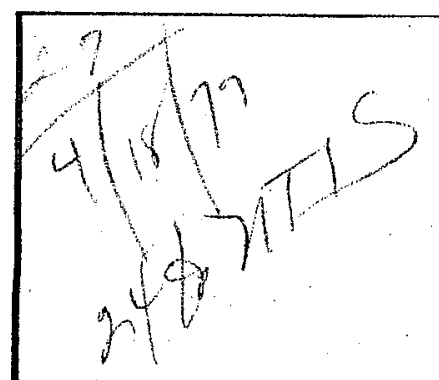

$\frac{\text { PNL-2690 }}{\text { UC-70 }}$

\section{Conceptual Design of a Nuclear Waste Vitrification Facility}
D. E. Larson
M. S. Hanson
H. T. Blair
L. S. Romero
W. F. Bonner
D. H. Siemens
A. A. Garrett

May 1978

Prepared for the U.S. Department of Energy under Contract EY-76-C-06-1830

Pacific Northwest Laboratory Operated for the U.S. Department of Energy by Battelle Memorial Institute 
NOTICE

This report was prepared as an account of work sponsored by the United States Government. Neither the United States nor the Department of Energy, nor any of their employees, nor any of their contractors, subcontractors, or their employees, makes any warranty, express or implied, or assumes any legal liability or responsibility for the accuracy, completeness or usefulness of any information, apparatus, product or process disclosed, or represents that its use would not infringe privately owned rights.

The views, opinions and conclusions contained in this report are those of the contractor and do not necessarily represent those of the United States Government or the United States Department of Energy.

\author{
PACIFIC NORTHWIEST LABORATORY \\ operated by \\ BATTELLE \\ for the \\ UNITED STATES DEPARTMENT OF ENERGY \\ Under Contract EY-76-C-06-1830
}

\author{
Printed in the United States of America \\ Available from \\ National Technical information Service \\ United States Department of Commerce \\ 5285 Port Royal Road \\ Springfield, Virginia 22757 \\ Price: Printed Copy $\$$; Microfiche $\$ 3.00$ \\ NTIS \\ *Pages Selling Price \\ $001-025 \quad \$ 4.50$ \\ 026-050 $\$ \$ 5.00$ \\ $051-075 \quad \$ 5.50$ \\ 076-100 $\$ 6.00$ \\ $101.125 \quad \$ 6.50$ \\ $126-150 \quad \$ 7.00$ \\ $151-175 \quad \$ 7.75$ \\ 176-200 $\$ 8.50$ \\ $201-225 \quad \$ 8.75$ \\ 226-250 \$9.00 \\ $251-275 \quad \$ 10.00$ \\ $276-300 \quad \$ 10.25$
}




\section{DISCLAIMER}

This report was prepared as an account of work sponsored by an agency of the United States Government. Neither the United States Government nor any agency Thereof, nor any of their employees, makes any warranty, express or implied, or assumes any legal liability or responsibility for the accuracy, completeness, or usefulness of any information, apparatus, product, or process disclosed, or represents that its use would not infringe privately owned rights. Reference herein to any specific commercial product, process, or service by trade name, trademark, manufacturer, or otherwise does not necessarily constitute or imply its endorsement, recommendation, or favoring by the United States Government or any agency thereof. The views and opinions of authors expressed herein do not necessarily state or reflect those of the United States Government or any agency thereof. 


\section{DISCLAIMER}

Portions of this document may be illegible in electronic image products. Images are produced from the best available original document. 

D. E. Larson
H. T. Blair
W. F. Bonner
A. A. Garrett
M. S. Hanson
L. S. Romero
D. H. Siemens

May 1978

Prepared for the U.S. Department of Energy under Contract EY-76-C-06-1830

Pacific Northwest Laboratory

Richland, Washington 99352

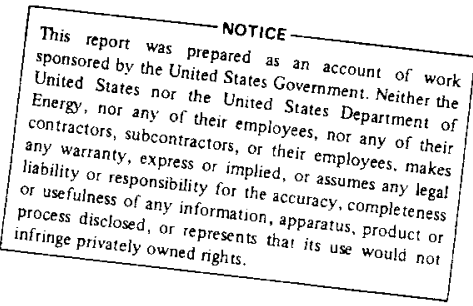


.
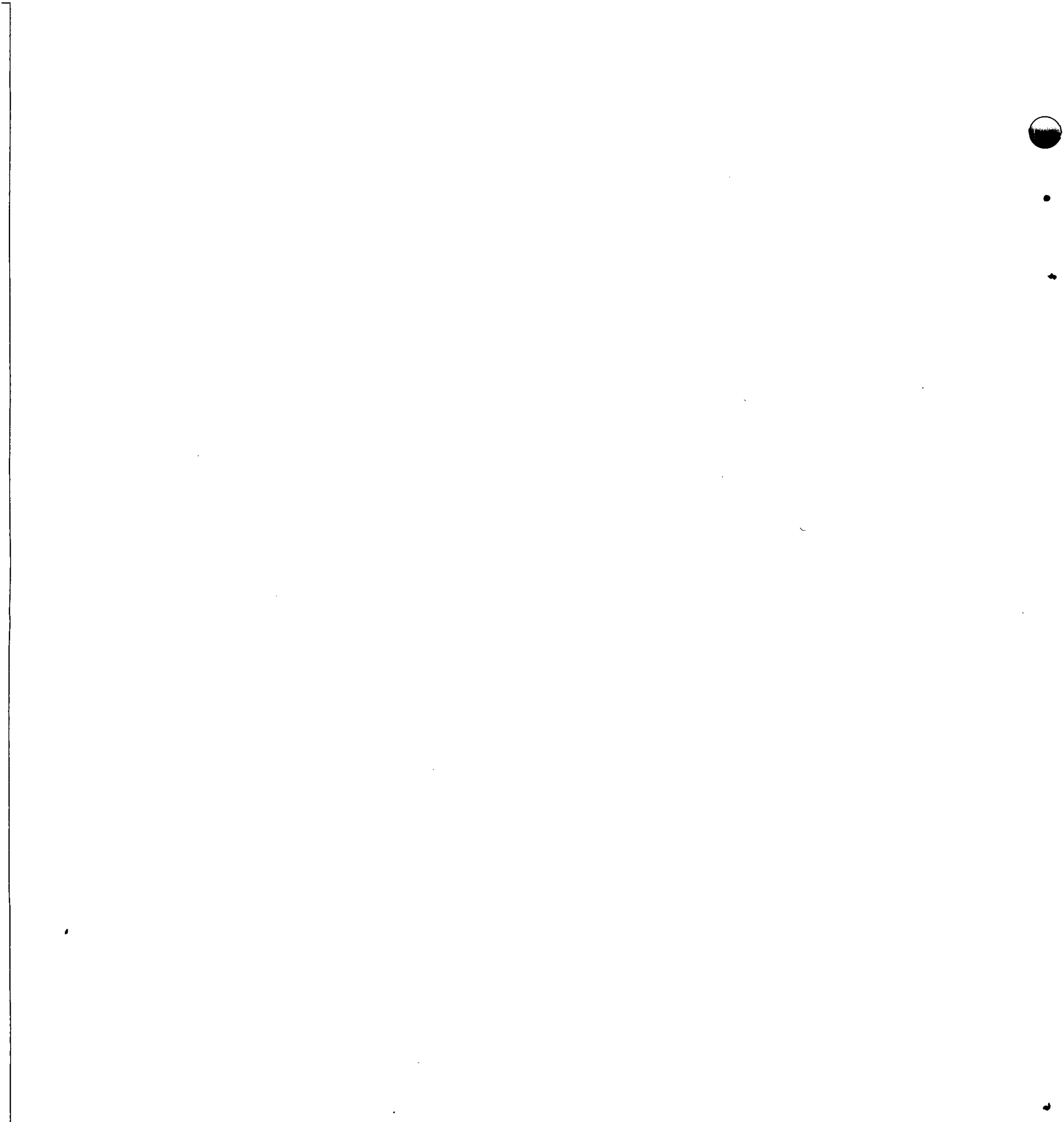

2

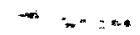


SUMMARY

This document describes a conceptual high-level waste immobilization facility. The report is part of a study conducted for the U.S. Department of Energy to facilitate the analyses of various nuclear fuel cycles and their effects upon the environment as part of a generic environmental impact statement. The facility would have the capability to calcine and then vitrify high-level liquid waste (HLLW). The vitrification would be accomplished in a canister which is seal-welded, checked for integrity, and decontaminated for movement to storage. Included in the facility would be the capability to repair faulty canister-lid seal welds, overpack failed canisters, and treat the process off-gas and cell ventilation air prior to release to the fue 1 reprocessing plant (FRP) atmospheric protection system (APS).

The nuclear waste vitrification facility (NWVF) would be an integral part of the FRP structure. It would therefore use the services, utilities, warehousing, offices, operating personnel change areas, and maintenance areas of the FRP. The operations of the facilities would be centered in the waste vitrification cell (WVC) which performs most of the facility functions. The cell is a reinforced concrete hot cell, lined with stainless steel, with internal dimensions of 8.5 by 9.7 by $16 \mathrm{~m}$ high ( 28 by 32 by $53 \mathrm{ft}$ high). Most operation and maintenance activities would be performed remotely using a crane equipped with an impact wrench or yoke. Other specialty activities would be performed by appropriate equipment such as master-slave manipulators, selfpropelled dollies, and other items. The major facility equipment includes a feed tank, spray calciner, two melters, weld-inspection stations, canister storage rack, and a canister decontamination cubicle. Installation and removal of equipment in the cell would be done through shielding doors. The air lock system of the canister decontamination cubicle would permit placement and removal of the canister. Activities in the cell may be observed through four shielding glass windows and/or up to three periscopes. The operating, service, and pipe galleries which house operating personnel and equipment necessary for cell operations are located adjacent to the cell. 
The NWVF would be designed and constructed according to Nuclear Regulatory Commission (NRC) licensing requirements to provide a licensable facility with a minimal impact on the environment. The siting and other facility requirements would be the same as requirements for the associated reprocessing plant. There would be no additional design or construction requirements. 


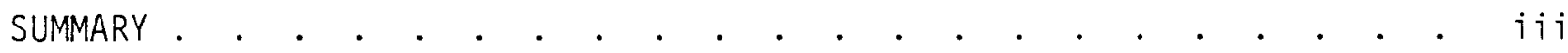

LIST OF TABLES

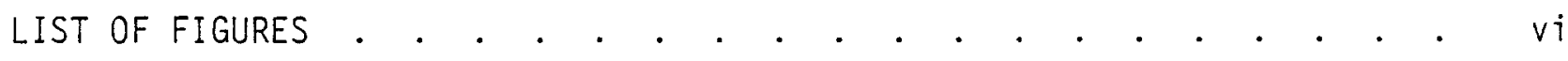

GLOSSARY . . . . . . . . . . . . . . . . . . i iX

INTRODUCTION . . . . . . . . . . . . . . . . . . . . . . .

PROCESS DESCRIPTION . . . . . . . . . . . . . . . . . . . 3

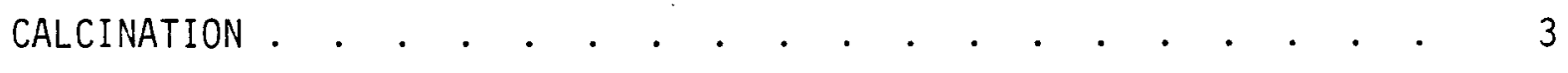

VITRIFICATION . . . . . . . . . . . . . . . . . . . . . 6

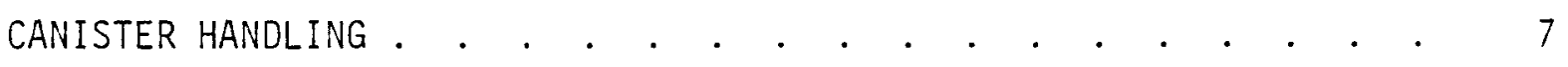

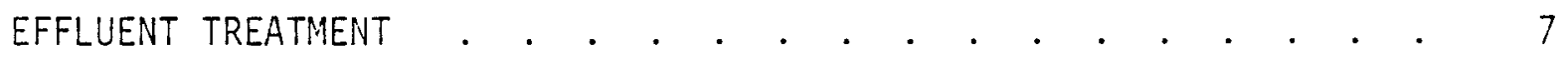

FACILITY DESIGN CRITERIA

FACILITY DESCRIPTION . . . . . . . . . . . . . . . . . . . 16

VITRIFICATION CELL . . . . . . . . . . . . . . . . . 20

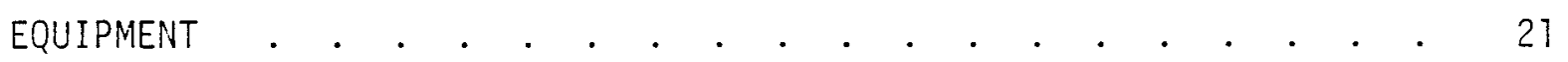

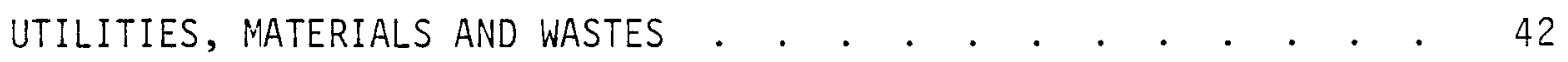

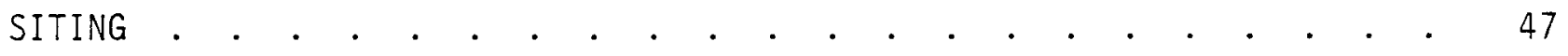

OPERATIONS . . . . . . . . . . . . . . . . . . . . . . . 48

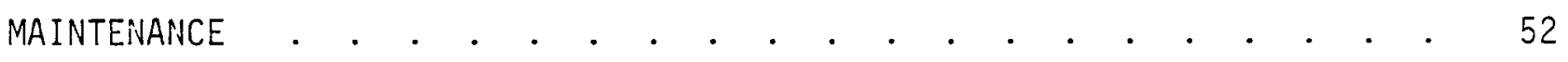

REFERENCES . . . . . . . . . . . . . . . . . . . . . . 54 


\section{$\underline{\text { IABLES }}$}

1 High-Level Liquid Waste Vitrification Flowsheet . . . . . . . 4

2 Canister Operating Time Cycle . . . . . . . . . . . . 7

3 Nuclear Waste Vitrification Facility Personnel Access Zone Classifications. . . . . . . . . . . . . . 10

4 Concentration of Reactor Fuel Products in High-Level Liquid Waste. . . . . . . . . . . . . . . . 12

5 Personnel Exposure Categories . . . . . . . . . . . . . 12

6 NWVF Areas and Associated Functions ............ . 19

7 Process Equipment . . . . . . . . . . . . . . . 22

8 Legend for Figures 5 Through 22 . . . . . . . . . . . . . . 23

9 Nuclear Waste Vitrification Facility Utilities and Essential Material Requirements . . . . . . . . . . . . . .43

10 Nuclear Waste Vitrification Faciltiy Waste Generation . . . . . 44

11 Allocated Facility Staffing Requirements. . . . . . . . . 50

\section{FIGURES}

1 Source of High-Level Waste in the Fuel Cycle. . . . . . . . . . 2

2 High-Level Liquid Waste Vitrification Flow Diagram. . . . . . . 5

3 High-Level Waste Vitrification Cell Plan View . . . . . . . . 17

4 High-Level Waste Vitrification Cell Elevation View. . . . . . . 18

5 Calciner Feed Tank. . . . . . . . . . . . . . 24

6 Calciner.................... . . 25



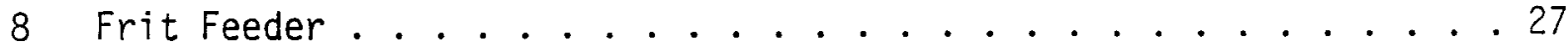

9 Calciner Condensate Tank. . . . . . . . . . . . 23

10 Decontamination Solution Tank . . . . . . . . . . . . 29

11 Canister Storage Rack . . . . . . . . . . . . . . . 30

12 Cell Air Filters. . . . . . . . . . . . . 31

13 Welding and Inspection Stations .................. 32

14 Calciner Condenser. . . . . . . . . . . . . . 33

15 Calciner Scrubber-Separator . . . . . . . . . . . . 34

16 Off-Gas Demister. . . . . . . . . . . . . . 35

17 I and Ru Sorber Feed Heaters. . . . . . . . . . . . . 36 
18 Ruthenium Sorber . . . . . . . . . . . . . . 37

19 Pre- and HEPA Off-Gas Filters. . . . . . . . . . . . . 38

20 Iodine Sorber. . . . . . . . . . . . . . . . . . 39

$21 \mathrm{NO}_{\mathrm{X}}$ Destructor. . . . . . . . . . . . . . . . . 40

22 Off-Gas Cooler. . . . . . . . . . . . . . . . . . 41

23 Spray Calcine Properties . . . . . . . . . . . . . . 46 


$\begin{array}{ll}\text { ALARA } & \text { as low as reasonably achievable } \\ \text { AMA } & \text { aqueous makeup area } \\ \text { APS } & \text { atmospheric protection system } \\ \text { CDC } & \text { canister decontamination cubicle } \\ \text { CSG } & \text { cell service gallery } \\ \text { CSR } & \text { canister storage rack } \\ \text { CVT } & \text { cell ventilation tunnel } \\ \text { DOE } & \text { Department of Energy } \\ \text { DST } & \text { decontamination solution tank } \\ \text { FRP } & \text { fuel reprocessing plant } \\ \text { HEPA } & \text { high efficiency particulate air } \\ \text { HLLW } & \text { high-level liquid waste } \\ \text { HMA } & \text { hot maintenance area } \\ \text { HPT } & \text { hot pipe trench } \\ \text { LWR } & \text { light water reactor } \\ \text { NRC } & \text { Nuclear Regulatory Commission } \\ \text { NWVF } & \text { nuclear waste vitrification facility } \\ \text { OA } & \text { operating area } \\ \text { PNL } & \text { Pacific Northwest Laboratory } \\ \text { SC/ICM } & \text { Spray Calcination/In-Can Melter } \\ \text { WSG } & \text { warm service gallery } \\ \text { WVC } & \text { waste vitrification cell }\end{array}$


CONCEPTUAL DESIGN

OF A NUCLEAR WASTE VITRIFICATION FACILITY

\section{INTRODUCTION}

This document describes a conceptual process and facility capable of solidifying high-level liquid waste (HLLW) by the Spray Calcination/In-Can Melter (SC/ICM) process. The document was prepared to support a generic environmental impact statement in which three alternative fuel cycles [light water reactor (LWR) once-through, LWR with $U$ recycle, LWR with $P U / U$ recycle] are being evaluated.

The HLLW is an aqueous waste produced by the solvent extraction processing (first cycle) of spent nuclear fuels for uranium and plutonium recovery. The HLLW contains over $99 \%$ of the fission products and transplutonium elements contained in the spent fuel, and thus incorporates most of the radioactivity associated with reprocessing LWR fuel. A flow diagram indicating the origin, treatment, and disposition of the waste, including HLLW, is shown in Figure 1. This conceptual facility would be included as part of a fuel reprocessing plant that reprocesses 2000 metric ton of heavy metal (MTHM) of spent fuel per year. The facility described herein has the capability to solidify and encapsulate HLLW, then perform inspection and decontaminate the filled canister. Also, additional information is included describing the operations, maintenance, and materials utilization for facility operation. Waste and effluent generation rates are also included. The facility description is based on HLLW waste solidification development work being performed by Pacific Northwest Laboratory (PNL) for the United States Department of Energy (DOE). 


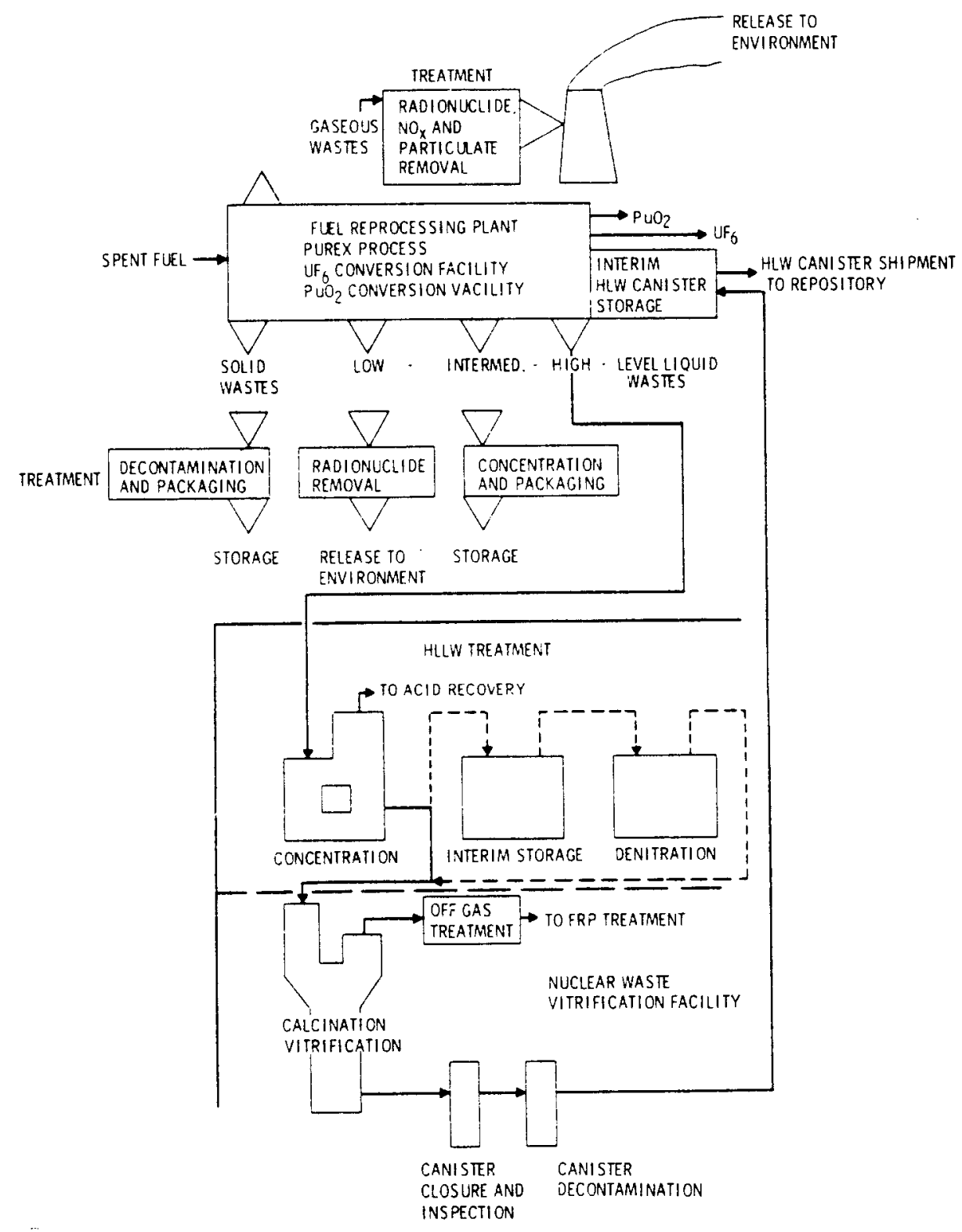

FIGURE 1. Source of High-Level Waste in the Fuel Cycle 


\section{PROCESS DESCRIPTION}

The SC/ICM process (1-7) developed at PNL converts HLLW to a glass in a container that is then sealed for shipment to a Federal repository. The process consists of basically four steps: 1) calcination, 2) vitrification, 3) canister handling, and 4) effluent treatment. These steps are shown in the flow diagram in Figure 2 . The process material balance is contained in Table 1 .

\section{CALCINATION}

The calciner decomposes the chemicals in the HLLW to a process off-gas and a metal oxide calcine which is suitable for making waste glass.

HLLW at $\leq 40^{\circ} \mathrm{C}$ in the calciner feed tank is pumped at a controlled rate to the calciner through a pneumatic atomizing spray nozzle. Before the waste solution contacts the calciner wall, which is maintained at about $700^{\circ} \mathrm{C}(600-$ $800^{\circ} \mathrm{C}$ ) by a multizone furnace, it is dried and then converted to oxides and reaction gases including $\mathrm{H}_{2} \mathrm{O}, \mathrm{HNO}_{3}$, air and $\mathrm{NO}_{x}$. There may also be some $\mathrm{CO}_{x}$ and other gases from the degradation of organics that may be contained in the HLLW.

The calciner off-gas, at a temperature of about $350^{\circ} \mathrm{C}$, is filtered by sintered stainless steel filters to remove entrained calcine. "Only about $0.1 \mathrm{wt} \%$ of the calcine passes through the filters and is then retained in the off-gas system. Less than $2 \%$ of the ruthenium is volatilized and escapes the calciner, but this ruthenium is retained in the off-gas system. All iodine and tritium in the HLLW volatilizes and is included with the calciner offgas. The balance of radionuclides remains in the calcine. The filters mounted on the calciner are periodically blown back with air to remove the accumulation of calcine.

Frit (a glass-forming additive) is metered into the calciner bottom at a rate proportional to the HLLW feed rate to the calciner. For most HLLW, about one part (by weight) of calcine is added to two parts of frit. The fritcalcine mixture drops from the calciner cone into a canister for melting. When one canister is full of glass, a diverter valve routes the calcine-frit mix to a second canister. 
TABLE 1. High-Leve1 Liquid

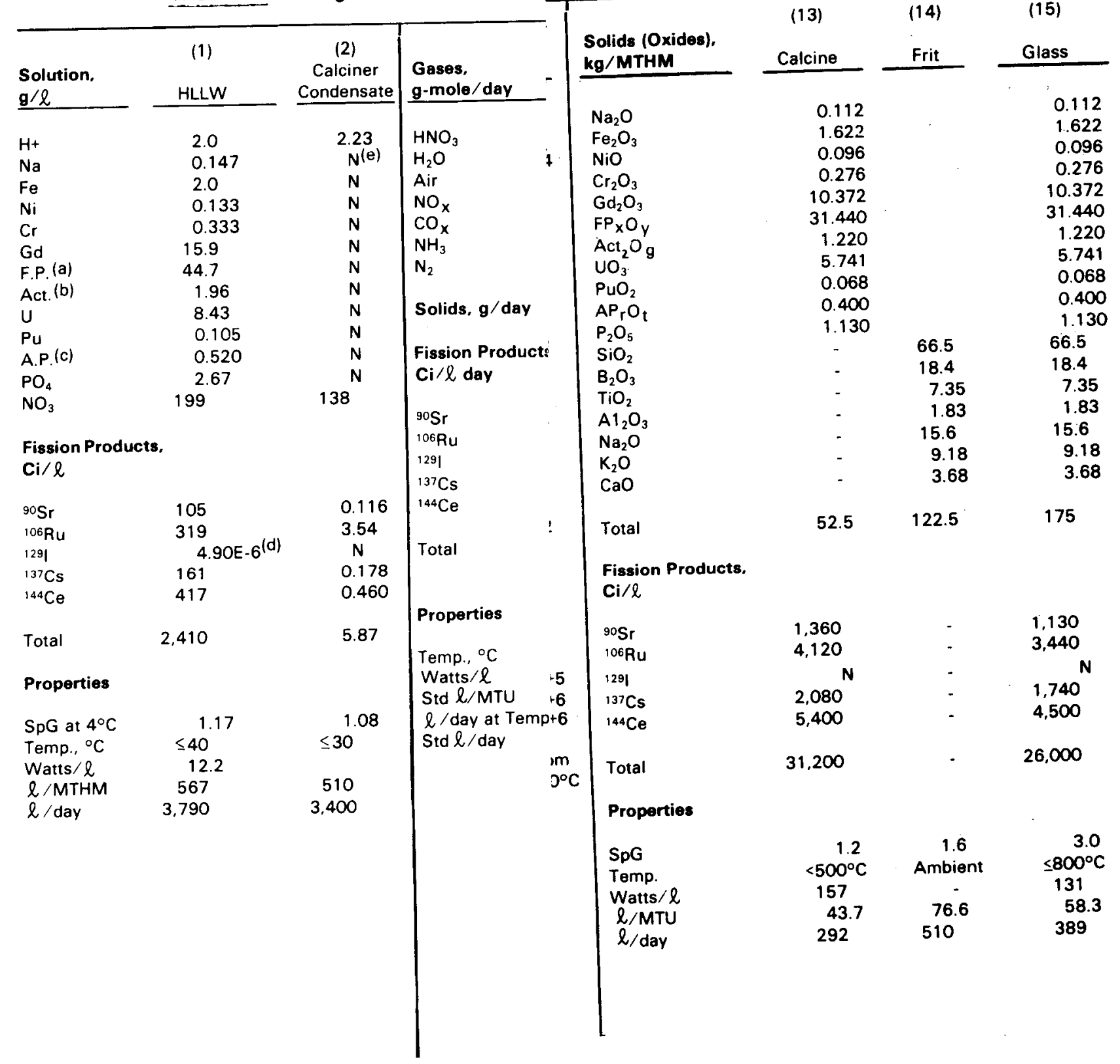

\footnotetext{
(a) F.P. = Fission Products

(b) Act. = Actinides

(c) A.P. = Activation Products

(d) Quantity sufficiently small that it is assumed negligible. Appr. 1299 in the Calciner Off-Gas would be included in the Calciner

(e) $N=$ Negligible
} 


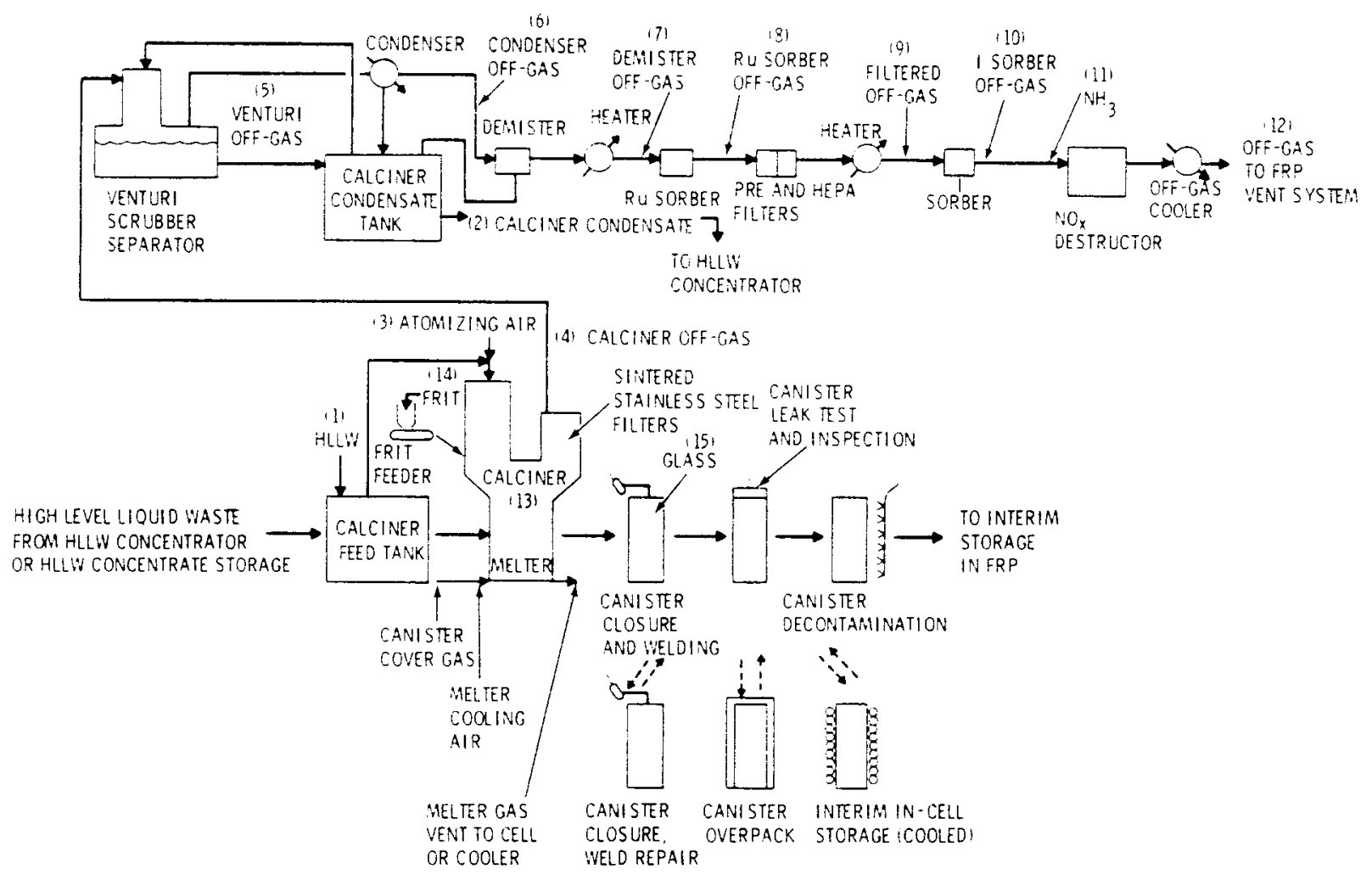

FIGURE 2. High-Level Liquid Waste Vitrification Flow Diagram

\section{VITRIFICATION}

The waste calcine vitrification is performed in a canister that is $30 \mathrm{~cm}$ in diameter by $300 \mathrm{~cm}$ high (12 in. in diameter by $10 \mathrm{ft}$ high) which is contained in the retort of the melter furnace. The calcine-frit mixture from the calciner flows into the canister where it is melted at $1050^{\circ} \mathrm{C}$ to form glass at a rate of $16.2 \mathrm{l} / \mathrm{hr}\left(0.57 \mathrm{ft}^{3} / \mathrm{hr}\right)$. Once the glass has formed, the heating is terminated, and cooling air is blown on the outer retort wa 11. This cools the wall and the canister to $\leq 800^{\circ} \mathrm{C}$. The canister is filled to $80 \%$ of its volume (contains HLLW from 3.04 MTHM). The smali volume of 
gas generated during the melting is routed to the calciner. Total time to fill the canister is about $11 \mathrm{hr}$ for the reference flowsheet.

If a stainless steel canister is used, an inert gas, such as argon, is used in the retort to control minor canister spalling during filling. Any spalled material is collected in a pan in the retort bottom and is removed for disposal, as necessary.

The filled canister is removed from the calciner connections, and the lid is placed on the canister. A prepackaged helium source may be placed in the canister prior to closure for use in later leak-testing. Then, the filled canister is moved on to seal-welding and inspection. The operating time cycle for filling a canister is shown in Table 2.

TABLE 2. Canister Operating Time Cycle Operations Time, $h r$

Place in Melter, Move Under Calciner, Connect

Heat Empty Can

Fill

Top and Allow Bubble Release

Cool

Disconnect,

Move Away from Calciner,

Remove from Melter

Time Lags

Total $\frac{1}{22}$


CANISTER HANDLING

The canister lid is seal-welded, using the tungsten inert gas process, to isolate the waste and canister interior from the outside environment. The canister weld is helium leak-checked to ensure its integrity (ultrasonic testing may also be used for this purpose). The canister is also visually inspected. Medium pressure water and/or steam sprays are used to remove any loose contamination from the filled canister. It is then moved to interim storage in the FRP. The vitrification cell will also provide for storage of empty and filled canisters. Additional inspection and process quality control functions can be designed into the facility, if necessary.

\section{EFFLUENT TREATMENT}

There are four sources of process effluents: calciner off-gas, canister decontamination solution, canister cooling air, and canister cover gas. Other effluents from the process area include cell ventilation air, vessel ventilation air and periodic cell decontamination solutions.

The calciner off-gas from the sintered stainless filters is subjected to a series of process operations to remove particulates (including radionuclides), gaseous radionuclides, and $\mathrm{NO}_{x}$. These steps, occurring prior to release to the atmospheric protection system (APS), include the following:

- quenching

- condensing

- mist elimination

- Ru sorption

- filtration

- I sorption

- $\mathrm{NO}$ destruction

The filled canisters are decontaminated with water and/or steam sprays to remove loose radioactive particulates such as calcine. The spray solution is accumulated in a tank and periodically recombined with HLLW prior to concentration. 
There are multiple gaseous waste handling systems. The canister cooling air and the canister cover gas are vented to the cell. Cell ventilation air is filtered to remove radioactive particulates prior to release to the FRP APS. The cell air filtration system will include one stage of roughing filters followed by two stages of high efficiency particulate air (HEPA) filters. The filters are periodically tested to ensure their interity. The vessel ventilation air is routed to the FRP vessel ventilation system.

Periodically some cell or equipment decontamination will be required. Steam, water, nitric acid, caustic, potassium permanganate, or tartaric acid will be used for this purpose. Decontamination solutions will be collected in the cell sump or other tanks and jetted to a waste accumulation tank for sampling. They will then either be combined with the HLLW or routed for treatment as intermediate-level liquid waste (ILLW). 


\section{FACILITY DESIGN CRITERIA}

The following design criteria provide guidance for appropriate, safe, and reliable functioning of the NWVF.

Regulations, Codes, and Standards

The facility would be 1 icensed by the NRC and thus will comply with federal, state, and local reguiations. The facility and equipment will be designed in accordance with nationally recognized codes and standards. The design will conform to applicable regulatory guides and criteria issued by NRC for nuclear reactors and fuels reprocessing plants.

\section{Operating Functions}

The following operations will be performed in the NWVF:

- Receive HLLW from a transfer tank

- Sample and adjust HLLW composition

- Feed HLLW to calciner

- Calcinate HLLW

- Vitrify calcine

- Place lid on canister

- Seal-weld lid on canister

- Integrity test seal weld

- Decontaminate filled canisters

- Interim storage of three empty and three filled canisters in cell

- Move canisters within, into, and out of cell

- Repair faulty seal welds

- Overpack failed canisters

- Treat calciner off-gas for release to APS

- Collect other waste, sump, and decontamination solutions for routing to further treatment

- Sample the sump collection and decontamination solution tanks. 
Operating Methods

A11 WVC operations will be performed remotely. Operations will typically use any number of devices: the crane which may be equipped with special devices such as a rotating hook, yoke, or impact wrench; dollies, and devices designed for special operations such as the welding head, lid leak testing head, and canister coupler to the calciner loading chute. Typical uses of the master-slave manipulators may be limited to placement of helium sources in canisters, placement of canister lids, replacement of instrument sensors and adjustment of the welding head. A11 WVC operations wil1 be performed and monitored from the control room by instrumentation, viewing through the shielding windows, or viewing through a periscope. Where practical for maximum efficiency, other NWVF operations should be performed and monitored from the control room.

\section{Maintenance Methods}

A11 WVC maintenance activities will be performed remotely with the in-cell crane which may be equipped with a yoke or an impact wrench. Use of the manipulators will be limited to replacing smal1, high frequency fajlure iteius such as parts on the canister-chute coupler or the welding head.

Other maintenance may be performed using contact, semiremote, or remote methods after the radiation and contamination hazards and available techniques have been assessed.

Functional Layout

The NWVF functions will be located in areas consistent with radiation and contamination criteria for personnel protection as indicated in Table 3 .

TABLE 3. Nuclear Waste Vitrification Facility Personnel Access Zone Classifications

Function

Waste Vitrification Cell and Hot Pipe Trench Hot Maintenance Area Warm and Cel1 Service Galleries Aqueous Make-Up and Operating Areas
Personnel Access

None

Limited

Controlled

Total 


\section{Process Capacity}

The facility would be designed to operate for $300 \mathrm{~d} / \mathrm{yr}$ and process waste at a rate of $5700 \mathrm{l} / \mathrm{d}(1500 \mathrm{gal} / \mathrm{d})$, although only a $3800 \mathrm{l} / \mathrm{d}(1000 \mathrm{gal} /$ d) flowsheet capacity is needed. The additional design capacity allows for process upsets and process variations. This capability would enable the processing of 211 the HLLW from an FRP reprocessing spent fuel at a rate of 2000 MTHM/yr.

\section{Equipment}

In general, in-cell equipment will be designed for simplicity of operation and maintenance. There will be minimal use of equipment with moving parts which are subject to high maintenance frequency. All equipment wi11 be designed and selected on the basis of suitability for intended use and high reliability. Major pieces of process equipment will be fabricated from materials exhibiting high resistance to corrosion, radiation damage, and process operating conditions. Similarly, all of the equipment, piping and instrument tubing in radioactive areas will be fabricated of materials that can withstand existing and anticipated decontamination solutions and radiation exposure. To aid in remote operations, equipment will be arranged to permit unobstructed crane access and will be equipped with lifting devices (7ugs, yokes, etc.).

Facility Design Basis Fue?

The fuel used as the basis for facility and equipment design has the following characteristics:

Type: Pressurized Water Reactor - Uranium Enriched

Enrichment: $3.3 \%{ }^{235} \mathrm{U}$

Burnup: 33,000 MWd/MTHM

Power Leve1: 30 MW/MTHM

Neutron Flux: $2.92 \mathrm{E} 13 \mathrm{~N} / \mathrm{cm}^{2}-\mathrm{sec}$

Time Out-of-Reactor: $180 \mathrm{~d}$

\section{HLLW Description}

The HLLW will have the composition shown in Table 1. This HLLW may contain some organic material from entrainment of Purex process solvent or 
denitration processing, but it contains no other FRP wastes. Table 4 indicates the assumptions used to determine the HLLW radionuclide content. The HLLW would have a concentration of 568 1iter/MTHM (150 gal/MTHM).

\section{TABLE 4. Percentage of Reactor Fuel Products} Appearing in High-Level Liquid Waste

\begin{tabular}{|c|c|}
\hline Isotope & $w t \%$ \\
\hline${ }^{3} \mathrm{H}$ & 8.0 \\
\hline${ }^{14} \mathrm{C}$ & 0.0 \\
\hline $\mathrm{kr}$ & 0.0 \\
\hline $\mathrm{Xe}$ & 0.0 \\
\hline I & 0.5 \\
\hline U & 0.5 \\
\hline $\mathrm{Pu}$ & 0.5 \\
\hline Other & 100.0 \\
\hline
\end{tabular}

\section{Radiation}

The facility will be designed so that personnel exposure will be controlled to "As Low As Reasonably Achievable" (ALARA) by area access control and by 1 imiting personnel exposure in significant radiation zones. Facility areas will be designed so they will fall into one of the personnel exposure categories listed in Table 5 .

TABLE 5. Personnel Exposure Categories

Maximum Allowable

Personnel Access

\begin{tabular}{c}
$\begin{array}{c}\text { Radiation Dose Rate, } \\
\text { mrem/hr }\end{array}$ \\
\hline$\leq 1$ \\
$\leq 10$ \\
$\leq 100$ \\
$>100$
\end{tabular}


Although personnel may be exposed to high radiation levels under nonroutine conditions, these controlled times will not exceed the limits established in 10 CFR 20.(8)

$\underline{\text { Safeguards }}$

Separation of the fissile materials contained in the HLLW for use in nuclear devices is impractical. The associated fission products and actinides will emit such an intense radiation field and will be so highly toxic as to prohibit handling of the material without heavily shielded and specialized facilities. Also, it would be very difficult to extract the plutonium from the other materials to make it useful as a fissile material because of the low concentrations.

The plant security force and controlled access techniques will also protect the HLLW from unauthorized movement.

Contamination Control

Radioactive contamination will be confined to appropriate facility areas such as process equipment and piping, the WVC niches and trenches. Confinement will be by several methods:

- Areas of higher contamination potential will be held at a negative pressure compared to areas of lower contamination potential.

- Ventilation air will flow from areas of lower contamination potential to areas of higher contamination potential.

- Potentialiy contaminated areas will be designed to either contain any solutions or solids spilled within the area itself or to send such spills to an area of higher potential contamination.

Sabotage

Since NWVF will be a part of the FRP it will be protected against acts of sabotage by the same methods and guard force that are used by the FRP to comply with 10 CFR 73 . (8)

Accidents and Safety

The facility will be licensed for construction and operation by the NRC. A key concern of 7 icensing requirements is the safety of operating 
personnel, local population, environment, and the facility. The facility will be designed to recover and resume operations after abnormal operations and accidents. Radionuclide releases from accident conditions will be controlled to within limits set by process technical specifications which are within federal regulations.

Criticality

The fissile material in the facility is not sufficient to be credibly assembled to make criticality a significant consideration.

\section{Qual ity Assurance}

A quality assurance program will be provided for the design and construction of the facility to assure it will meet all of the requirements. The program will comply to 10 CFR 50, Appendix B. (8)

Useful Life

The NWVF. will be designed and constructed so that it will have a useful operational life of $30 \mathrm{yr}$ based on the following design considerations:

- every component will be designed for maintenance under operating conditions;

- a quality assurance program will be developed for all aspects of design, procurement, construction and operation; and

- inaterials will be of known durability, and allowances will be made for radiation damage, corrosion and wear.

\section{Decommissioning}

Decontamination and decommissioning of the NWVF must be considered. Appropriate decontamination equipment and systems must be provided, and the monitoring and recording equipment must be incorporated to assess contamination levels. Materials and equipment will be selected for their ultimate ease of retirement and removal. A removable surface will cover facility structure surfaces which are highly susceptible to significant contamination with radionuclides that would be difficult to remove.

A decommissioning plan will be developed as part of the design. Guidance will be taken from the proposed standard, N 300-1974, Draft 7 , 
August 28, 1974, of American National Standards Institute, Inc., "Design Criteria for Decommissioning of Nuclear Fuel Reprocessing Plants," or a later issue. A decommissioning plan will be developed as part of the design.

It is projected that at the end of the facility's operating life the WVC and associated equipment will have become contaminated with $10 \mathrm{kCi}$ of mixed fission products that have been out of the reactor five years. 
$\bullet$ .

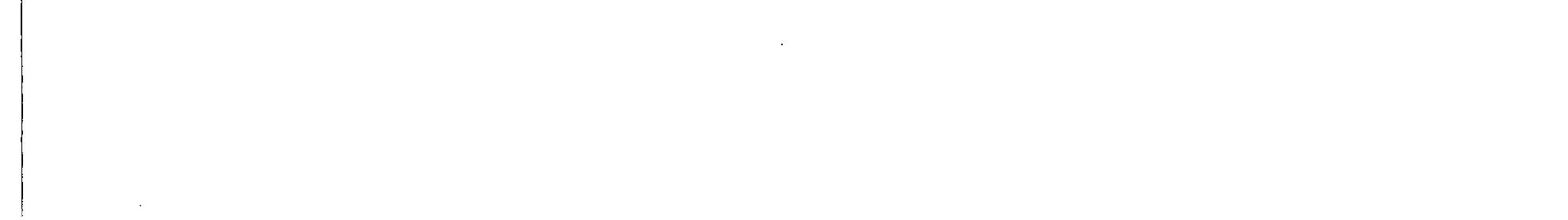

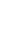

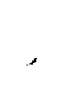

.

.






\section{FACILITY DESCRIPTION}

Calcination, vitrification, canister handling, and limited effluent treatment will take place in a single cell, which is described in this section. Some associated operating and service areas are partially included in the facility description. Services such as utilities, maintenance, air supply, final effluent treatment, personnel support, and other services which would support and/or be an integral part of the FRP are not described here. However, they are identified so they can be properly accounted for in the system requirements.

The NWVF will be a reinforced concrete structure (Figures 3 and 4 ) consisting of nine areas (see Table 6 ). This report describes in detail only the waste vitrification cell (WVC) and associated equipment since other indicated areas are dependent on the design and layout of the FRP. However, the operations and interfaces of these other areas with the WVC are described. Utilities such as cooling water, process water, steam, electricity, instrument air, ventilation air and emergency utilities will be provided to the areas 1 isted in Table 6 from central sources for the FRP. Other services such as analytical capabilities, personnel comfort and change rooms, instrument and manipulator maintenance, and warm equipment maintenance will also be provided as part of the integrated FRP complex.

Filled canisters will be stored in the fuel receiving pool, or a waste canister storage pool, and the empty canisters will be stored in the FRP warehouse as will other equipment for the operations of the WVC. If a future decision is made that shipping a canister of vitrified HLLW to a Federal repository will normally require overpacking, then the necessary facilities will be installed in the FRP. 


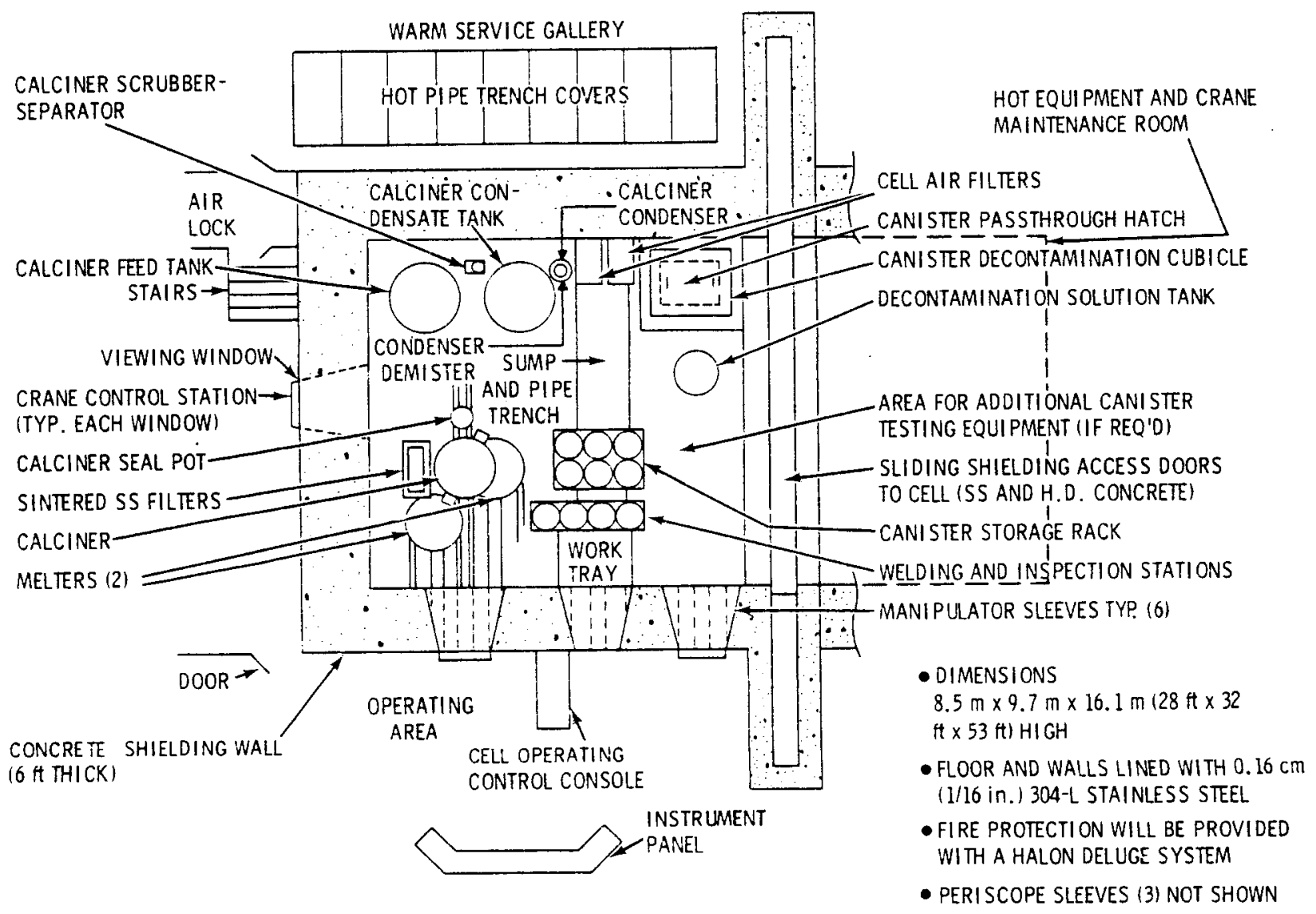

FIGURE 3. High-Level Waste Vitrification Cell Plan View 


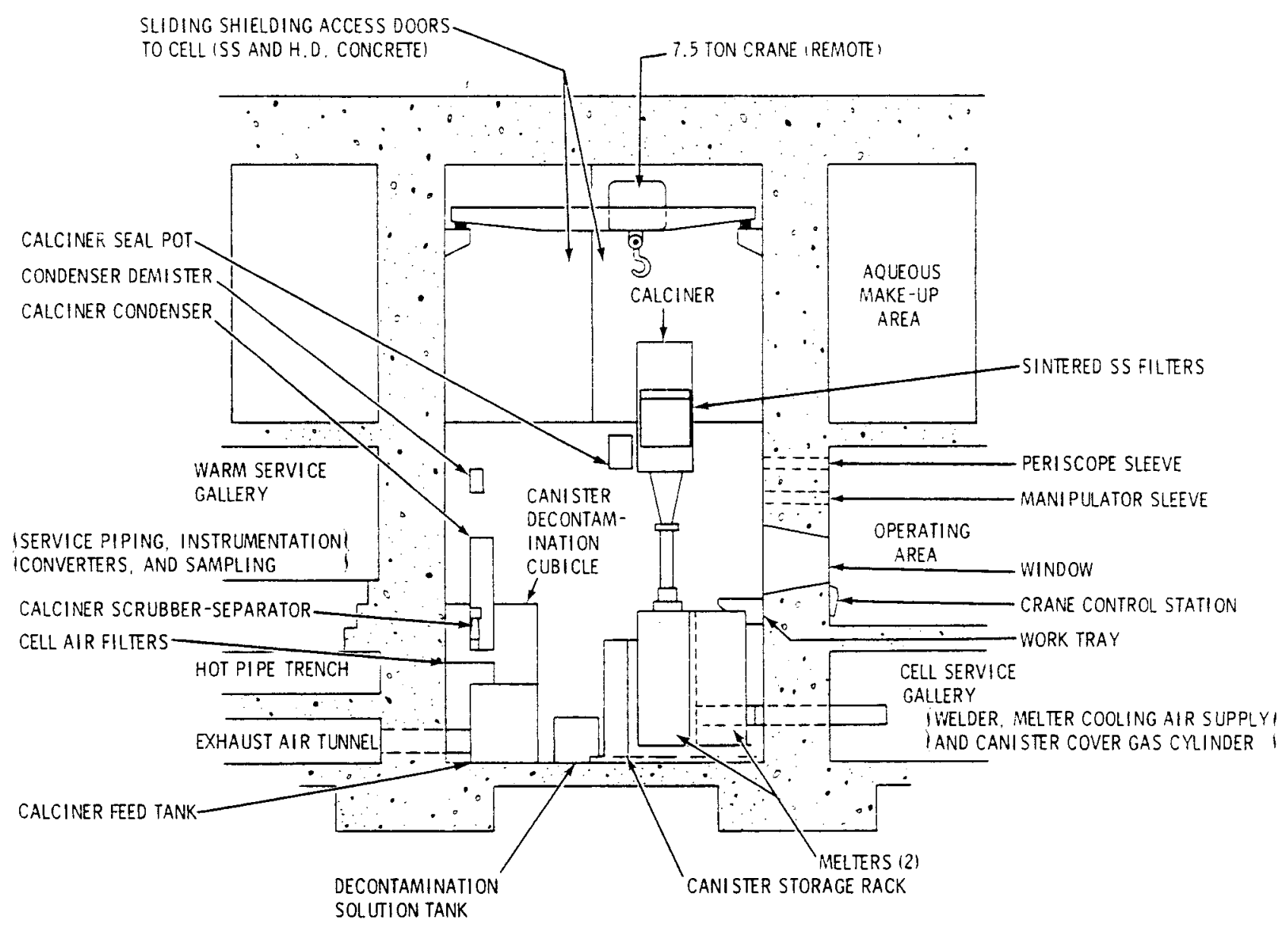

FIGURE 4. High-Level Waste Vitrification Cell Elevation View 
TABLE 6. Nuclear Waste Vitrification Facility

Areas and Associated Functions

Area

Waste Vitrification Cell

(WVC)

Canister Decontamination Cubicle (CDC)

Cell Ventilation Tunnel (CVT)

Hot Pipe Trench (HPT)

Operating Area (OA)

Hot Maintenance Area (HMA)

Warm Service Gallery (WSG)

Cell Service Gallery (CSG)

Aqueous Makeup Area (AMA)
Function

Receive, vitrify and package HLLW; inspect canister; 1 imited process off-gas treatment; filter cell air; handle cell waste.

Move canisters into and out of WVC, and decontaminate filled canisters.

Route air from contaminated building cells to the FRP APS.

Route radioactive solutions between WVC and other FRP process areas.

Perform process control and monitoring.

Provides for equipment access and allows repairs to be made from WVC (access gained through shielding doors).

Provides access to HPT, some WVC instrumentation converters and transmitters, samplers for WVC solutions, and service piping.

Contains cold equipment, services and controls for WVC operations such as welder, melter cooling air supply, canister cover gas, and melter umbilical pipe drive.

Contains frit storage and feed system, chemical solution makeup for use in WVC, and materials storage. 
VITRIFICATION CELL

The vitrification cell will be a reinforced concrete structure with interior dimensions of $8.5 \mathrm{~m}$ wide $\times 9.7 \mathrm{~m}$ long $\times 16 \mathrm{~m}$ high (28 $\mathrm{ft}$ wide, $32 \mathrm{ft}$ long and $53 \mathrm{ft}$ high) as shown in Figures 3 and 4 . The cell walls will be constructed of ordinary reinforced concrete. If it is deemed desirable to substitute high density concrete or other materials to accommodate cell penetrations or equipment, this may be done providing the shielding equivalence is maintained. The cell walls will be $1.8 \mathrm{~m}(6 \mathrm{ft})$ thick to reduce the radiation dose rate at the outer wall to $s 1 \mathrm{mrem} / \mathrm{hr}$. The cell floor is assumed to be on or below the ground which will supply shielding and eliminate personnel access from this direction. Also, the roof may be less than $1.8 \mathrm{~m}(6 \mathrm{ft})$ thick if personnel access is 1 imited. The entire cel1 will be lined with $304-\mathrm{L}$ stainless steel which is about $0.16 \mathrm{~cm}(1 / 16 \mathrm{in.})$ thick. This liner will aid in cell decontamination and decommissioning and will aiso protect the cell walls from corrosive chemicals and vapors.

The floor structure will include a combination service trench and sump $0.61 \mathrm{~m}$ wide by $0.61 \mathrm{~m}$ deep by $8.5 \mathrm{~m}$ long ( $2 \mathrm{ft}$ wide, by $2 \mathrm{ft}$ deep by $28 \mathrm{ft}$ long) covered with a $0.95-\mathrm{cm}-(3 / 8-\mathrm{in.}-)$ thick $304-\mathrm{L}$ stainless steel, removable plate. The trench will contain a cell sump and service pipe running to the weld and inspection station (WIS), canister storage rack (CSR) and the decontamination solution tank (DST). The cell floor will be sloped toward the trench.

The main equipment access to the cell will be through the shielding doors leading to the hot maintenance area (HMA). The doors will be sealed when closed to minimize air in-leakage from this area. The second access will be through the canister decontamination cubicle (CDC). Through this cubicle, empty and full canisters will be moved into or out of the cell, and full canisters will be decontaminated upon removal from the cell. This cubicle cover will not be airtight, but in-leakage will be minimized. Ventilation air will be supplied to the cell from minor in-leakage and through a filtered air supply.

The CDC within the cell will have internal dimensions of 1.2 m wide $\times 1.5 \mathrm{~m}$ long $\times 3.7 \mathrm{~m}$ high ( $4 \mathrm{ft}$ wide $\times 5 \mathrm{ft}$ long by $12 \mathrm{ft}$ high). The wal1 $\mathrm{s}$ will be of $0.61-\mathrm{m}-(2-\mathrm{ft}-)$ thick concrete and 1 ined with $0.16-\mathrm{cm}(1 / 16-\mathrm{in}$. 
304-L stainless steel. The cubicle will be equipped with spray bars supplied with decontamination solution from a medium pressure pump in the DST and a sump equipped with a steam jet to move decontamination solution back to the pump tank.

The cell wall will contain four shielding windows to enable viewing and guiding operations within the cell. Penetrations in the cell wall that will accommodate services such as master-slave manipulators, periscopes, a prepackaged helium source pass-through, two melter umbilical pipes, cell monitoring instrumentation, and equipment operation instrumentation. Service piping from the hot pipe trench to the adjacent cell remote heads will be cast into the cell wall. Service piping required from the hot pipe trench or cold side to the cell side walls will be routed through recesses in the cell wall behind the cell liner. There will also be a sump on the cell floor under the liner which will drain to a cell sump header.

Cel1 equipment will be mounted on ears, yokes, or racks on the walls and guides or supports on the floor. The crane will move on rails built into the cell walls. The melters will move on rails mounted on the cell floor.

Some empty floor space will be left in the cell to accommodate any additional canister test equipment required by federal waste acceptance criteria. If federal repository waste acceptance criteria require that all canisters be overpacked prior to shipment to a federal repository, this operation will be performed in another facility in the FRP.

\section{EQUIPMENT}

Major equipment for the SC/ICM process is described in this section and in Figures 5-22. Table 7 lists the equipment. All major process equipment will be remotely operated and maintained. With the exception of the calciner off-gas heaters, ruthenium sorber, off-gas filters, iodine sorber, $\mathrm{NO}_{x}$ destructor, and off-gas cooler, this equipment will be contained in the WVC. The pieces of equipment that are not in the WVC will be located in cells (such as the HLLW storage cell, HLLW concentration cel1, or FRP vessel ventilation cell) to separate them from an area with significant airborne contamination. Except for the ruthenium sorber and perhaps the off-gas 
TABLE 7. Process Equipment

\begin{tabular}{lc}
\multicolumn{1}{c}{ Process Equipment } & Figure \\
(Legend) & (Table 8$)$ \\
Calciner Feed Tank & 5 \\
Calciner & 6 \\
Melter & 7 \\
Frit Feeder & 8 \\
Calciner Condensate Tank & 9 \\
Decontamination Solution Tank & 10 \\
Canister Storage Rack & 11 \\
Cell Air Filters & 12 \\
Welding and Inspection Stations & 13 \\
Calciner Condenser & 14 \\
Calciner Scrubber-Separator & 15 \\
Off-Gas Demister & 16 \\
I and Ru Sorber Feed Heaters & 17 \\
Ruthenium Sorber & 18 \\
Pre- and HEPA Off-Gas Filters & 19 \\
Iodine Sorber & 20 \\
NOX Destructor & 21 \\
Off-Gas Cooler & 22
\end{tabular}


TABLE 8. Legend for Figures 5 Through 22

RACK OR PANEL MOUNTED

LOCALLY OR IN- LINE MOUNTED

OO TWO MEASURED VARIABLES

Flow ELEMENT

M MOTOR

ه DIAPHRAGM OPERATED VALVE

$\$$

\$ SOLENOID OPERATED VALVE

Í BALL VALVE

\begin{tabular}{|c|c|}
\hline AM & AMMETER \\
\hline AS & AIR SUPPLY \\
\hline ATM & ATMOSPHERE \\
\hline $\mathrm{Cl}$ & CIRCUIT INTERR UPTER \\
\hline DPA & DIFFERENTIAL PRESS URE ALARM \\
\hline & DIFERENTIAL PRES S URE INDICATOR \\
\hline DPR & DIFFERENTIAL PRESSURE RECORDER \\
\hline DPT & DIFFERENTIAL PRESS URE TRANSMITTER \\
\hline DR & DENSITY OR SPECIFIC GRAVITY RECORDER \\
\hline ETM & ELAPSED TIME METER \\
\hline FA & FLOW ALARM \\
\hline FC & FLOW CONTROLLER \\
\hline & FLOW SENSING ELEMENT \\
\hline $\mathrm{FI}$ & FLOW INDICATOR \\
\hline FR & FLOW RECORDER \\
\hline FT & FLOW TRANSMI TER \\
\hline FY & CONVERTER \\
\hline HLA & HIGH LEVEL ALARM \\
\hline$\Delta H W$ & HIGH WEIGHT RATE CHANGE ALARM \\
\hline IAS & INSTRUMENT AIR SUPPLY \\
\hline ic & IONIZATION CHAMBER \\
\hline is & CURRENT SWITCH \\
\hline IY & RELAY \\
\hline $\mathrm{JR}$ & ELECTRICAL POWER RECORDER \\
\hline is & ELECTRICAL POWER SWITCH \\
\hline $\mathrm{KJC}$ & TIMER \\
\hline LC & LOAD CELL \\
\hline LLA & LIQUID LEVEL ALARM \\
\hline LLI & LIQUID LEVEL INDICATOR \\
\hline LLR & LIQUID LEVEL RECORDER \\
\hline$\Delta \mathrm{LW}$ & LOW WEIGHT RATE CHANGE ALARM \\
\hline PCV & PRESS URE CONTROL VALVE \\
\hline PE & PRESSURE SENSING ELEMENT \\
\hline & ROGRAMMER \\
\hline
\end{tabular}

乘-NEEDLE VALVE

th REVERSE FLOW CHECK VALVE

-1- RESTRICTING FLOW ORIFICE

$\rightarrow$ TA-JET MIXER

_- PROCESS SERVICE LINES

A PNEUMATIC INSTRUMENT LINES

- PRIMARY PROCESS LINES

----ELECTRONIC WIRES OR HIDDEN LINES

PI PRESSURE INDICATOR

PR PRESSURE RECORDER

$\triangle P R$ CHANGE IN PRESSURE RECORDER

PS PRESSURE SWITCH

RC RATIO CONTROLLER

REF REFERENCE PRESSURE HEADER

RR RADIATION RECORDER

RW RAW WATER (UNSANITARY)

SE SENSING ELEMENT

SPL SAMPLE

SS STEAM SUPPLY

SUM SUMMER

SW SELECTOR SWITCH

TA TEMPERATURE ALARM

TC TEMPERATURE CONTROLLER

TE TEMPERATURE ELEMENT

II TEMPERATURE INDICATOR

TR TEMPERATURE RECORDER

TRC TEMPERATURE RECORDER CONTROLLER

$\Pi$ TEMPERATURE TRANSMITIER

VC VALVE CONTROLLER

VIB VIBRATOR

$\triangle W A$ WEIGHT RATE CHANGE ALARM

WC WEIGHT CONTROLLER

$\triangle W C$ WEIGHT RATE CHANGE CONTROLLR

$\triangle W I$ WEI GHT RATE CHANGE INDICATOR

$\Sigma \triangle W I$ WEIGHT TOTAL AND RATE CHANGE INDICATOR

WR WEIGHT RECORDER

$\triangle$ WR WEIGHT RATE CHANGE RECORDER

WS WEIGHT SUPPLY 


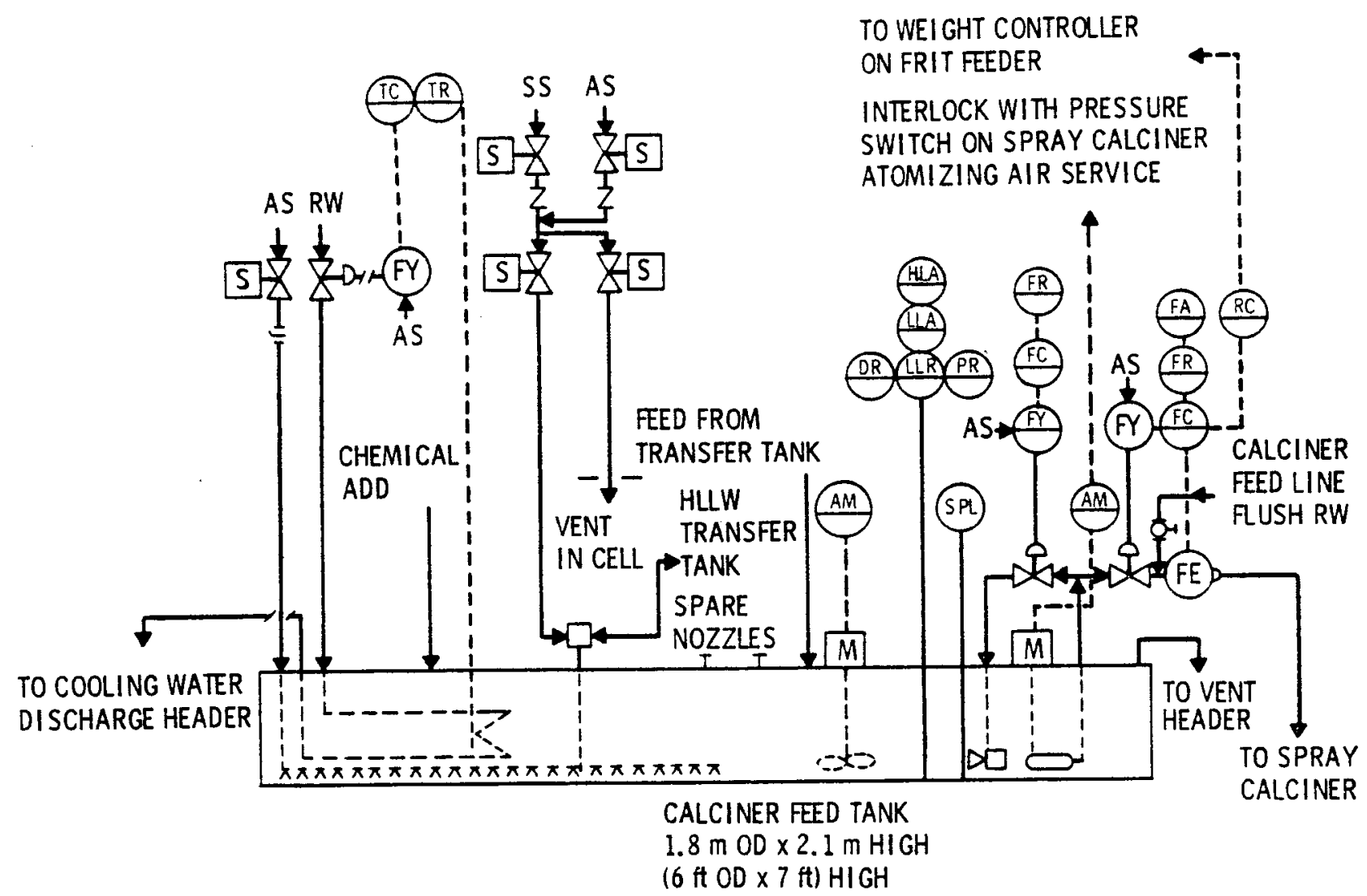

OPERATING CONDITIONS

VOLUME: $1200 \mathrm{GAL}(4500 \ell)$

PRESSURE: $0.97 \mathrm{~atm}$

TEMPERATURE: $40^{\circ} \mathrm{C}$

CALCINER FEED FLOW RATE: $2.6 \mathrm{l} / \mathrm{min}$ DESIGN PARAMETERS

VOLUME: $1500 \mathrm{GAL}$ (5700 \&)

PRESSURE: $0.5-1.5 \mathrm{~atm}$

TEMPERATURE: $0-110^{\circ} \mathrm{C}$

HEAT REMOVAL: $\leq 120 \mathrm{~kW}$

CALCINER FEED FLOW RATE: $0.4-4 \mathrm{l} / \mathrm{min}$

AGITATION: AIR SPARGE RING PROPELLER AGITATOR MIXING JET

TRANSFER JET CAPACITY (TYPE -STEAM):

$25 \mathrm{gpm}(\sim 100 \ell / \mathrm{min})$

MATERIAL: $304-$ STAINLESS STEEL NOTES:

FEED SYSTEM:

PUMP: TYPE: CANTILEVER

CAPACITY: $200 \mathrm{gpm}$ ( $757 \mathrm{\ell} / \mathrm{min})$ HEAD: $160 \mathrm{ft} \mathrm{H}_{2} \mathrm{O}(4.7 \mathrm{~atm})$

FLOWMETER: MAGNETIC

FLOW CONTROL VALVE: HAMMEL-DAHL DIAPHRAGM CONTROL VALVE WITH SPLINE PLUG OR EQUIVALENT

TANK MATERIAL THICKNESS: $0.64 \mathrm{~cm}(1 / 4 \mathrm{in.})$

FIGURE 5. Calciner Feed Tank 


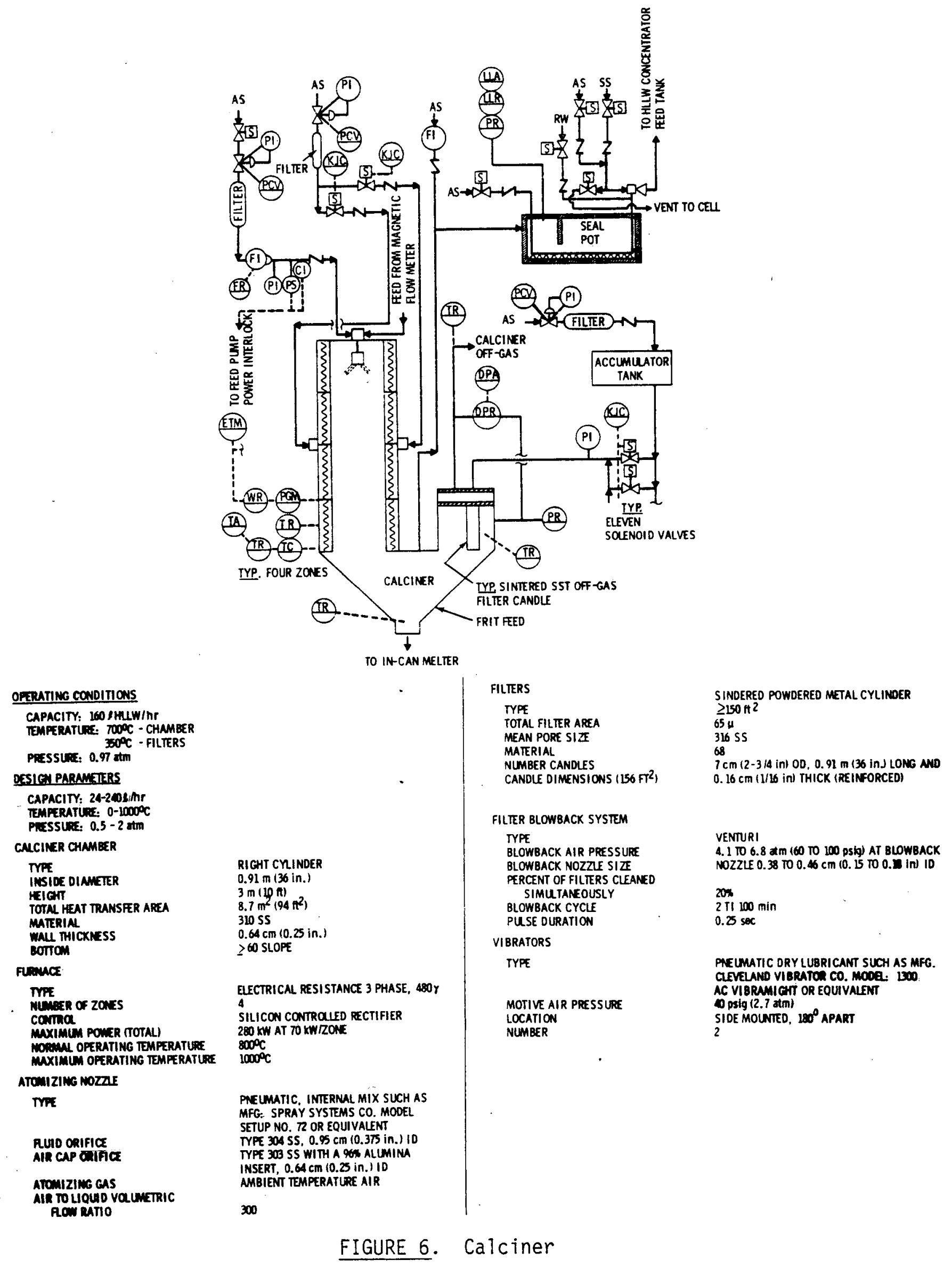




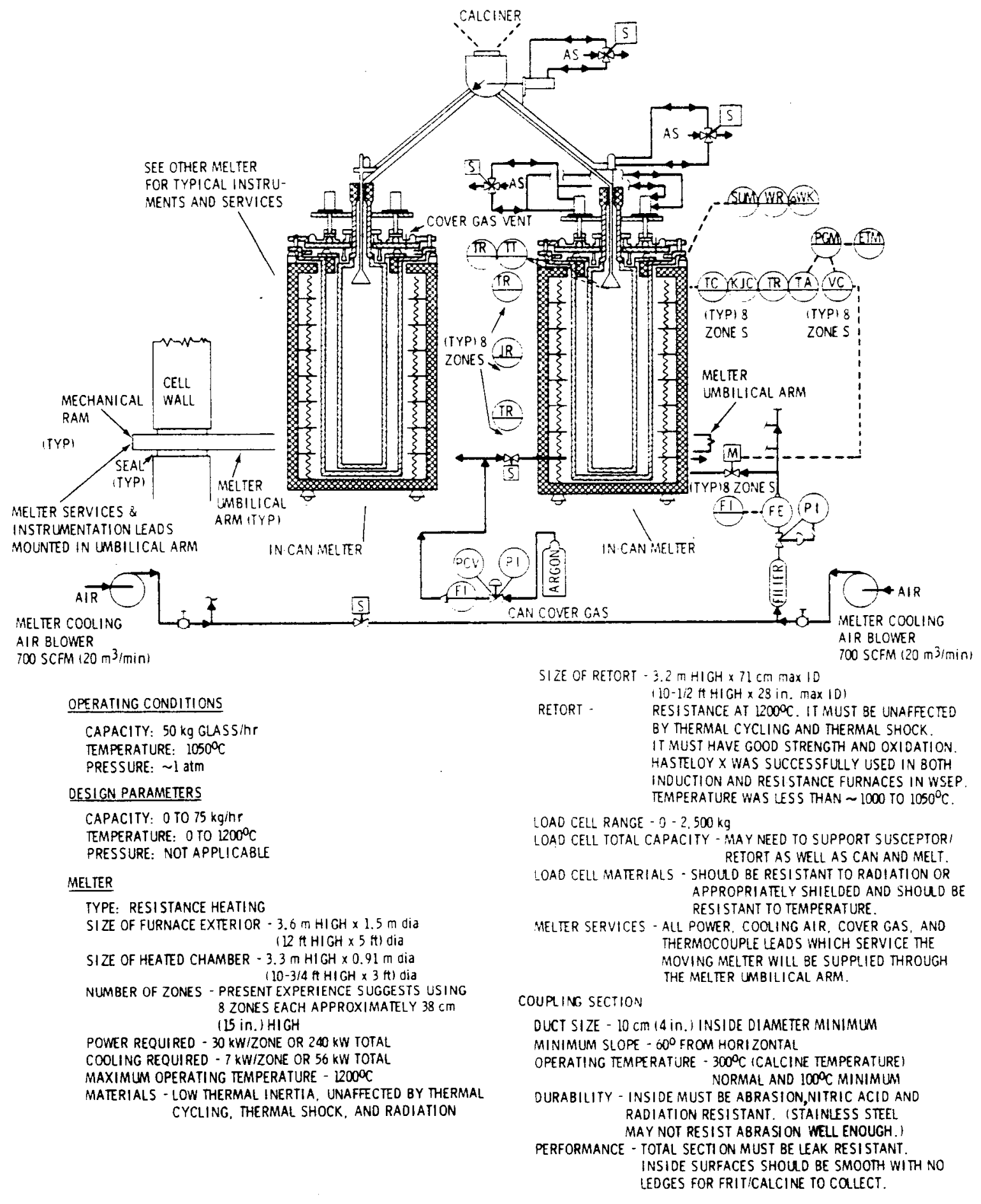

\section{FIGURE 7. Mel ter}




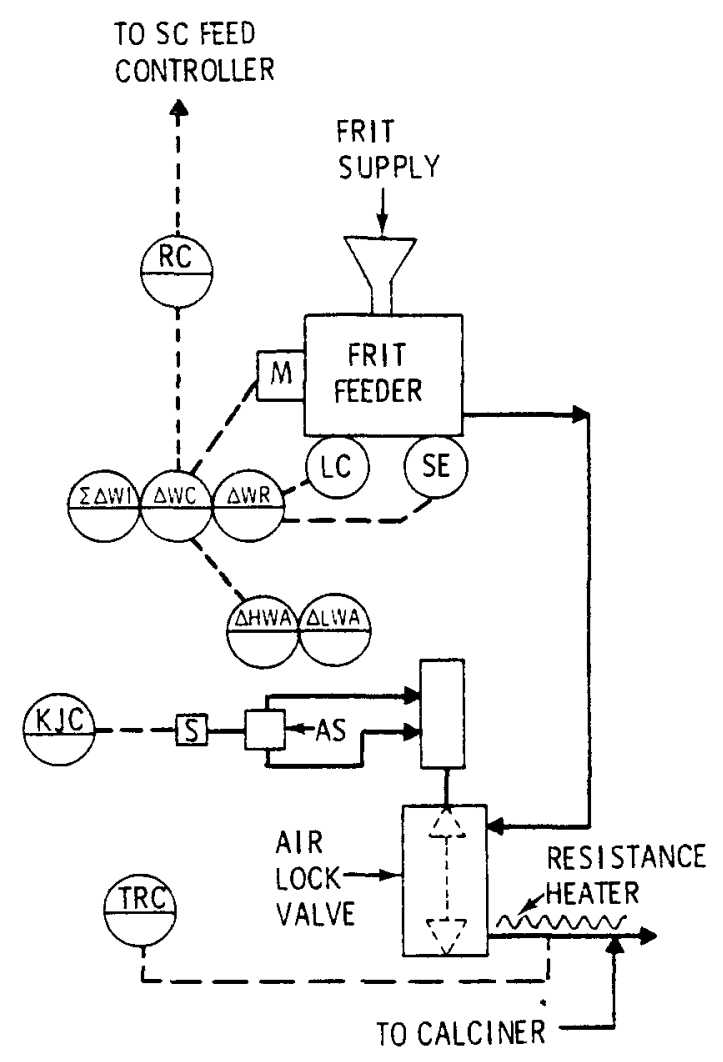

FRIT FEEDER

FRIT FEEDER

OPERATING CONDITIONS

NOMINAL FEED RATE: $34 \mathrm{~kg} / \mathrm{hr}$

TEMPERATURE: ROOM

PRESSURE: $1 \mathrm{~atm}$

\section{DESIGN PARAMETERS}

TYPE - VARIABLE SPEED, CONTINUOUS WEIGHT BELT

FEED RATE - 0-55 kg/hr

BIN SIZE - $1225 \mathrm{~kg}$ OF FRIT (510 l/DAY)

(FRIT: SIZE - -20I+80 MESH; SPECIFIC GRAVITY: 1.61
CONTROL - THE FEEDER MAY OPERATE AS A SLAVE FEEDER BY METERING FRIT AT A RATE PROPORTIONAL TO THE FLOW RATE OF LIQUID WASTE TO THE CALCINER.

MAINIENANCE - THE BIN, SCALES, AND FEEDER WILL BE OUTSIDE THE HOT CELL SO THAT THEY NEED NOT BE RADIATION RESISTANT AND HANDS -ON MAINTENANCE IS POSSIBLE. THE DUCTS AND AIRLOCKIS) SHOULD BE MADE OF ABRASION RESISTANT MATERIALS.

PERFORMANCE - THE AIRLOCKS MUST MINIMIZE BACK MIGRATION OF CONTAMINATION. A DUCT ANGLE OF 450 FROM VERTICAL IS ADEQUATE FOR GRAVITY FLOW OF THE FRIT THAT IS $-20 /+80$ MESH.

FIGURE 8. Frit Feeder 


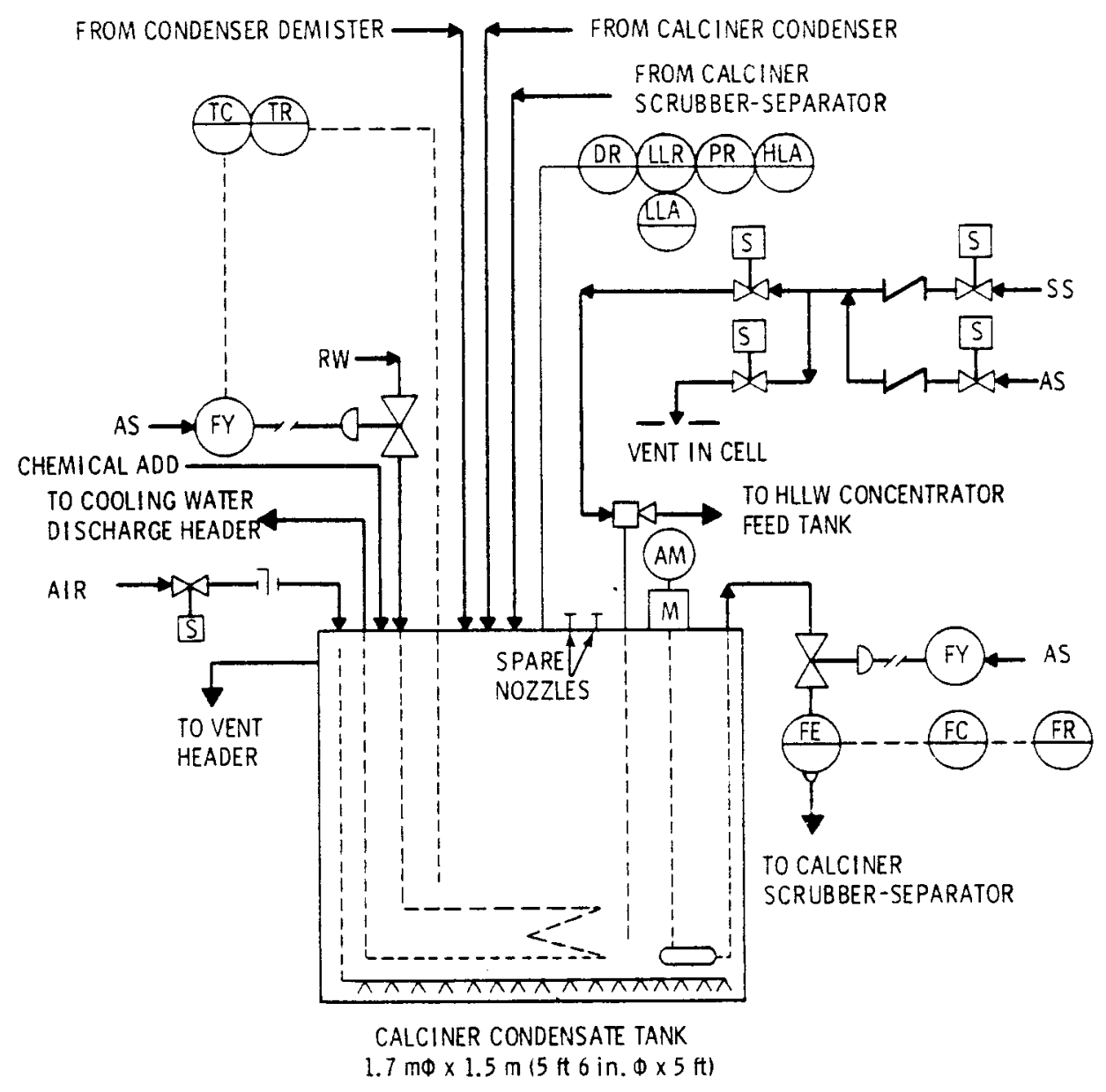

OPERATING CONDITIONS

VOLUME: $2650 \& 1700 \mathrm{GAL})$

PRES SURE: $0.97 \mathrm{~atm}$

TEMPERATURE: $\sim 29^{\circ} \mathrm{C}$

SCRUBBER FLOW RATE: $190 \mathrm{\ell} / \mathrm{min}$

DESIGN PARAMETERS

VOLUME: $3400 \boldsymbol{\ell}(900 \mathrm{GAL})$

PRESSURE: $0.5-1.5 \mathrm{~atm}$

TEMPERATURE: $0-110^{\circ} \mathrm{C}$

HEAT REMOVAL: $\leq 130 \mathrm{~kW}$

SCRUBBER FEED FLOW RATE: $40-320 \ell / \mathrm{min}$
AGITATION: AIR SPARGE RING

TRANSFER JET CAPACITY (TYPE: STEAM):

$\sim 100 \mathrm{l} / \min (25 \mathrm{gpm})$

MATERIAL: $304-\mathrm{L}$ STAINLESS STEEL

NOTES:

SCRUBBER FEED SYSTEM

PUMP: TYPE: CENTRIFUGAL

CAPACITY: $320 \mathrm{l} / \mathrm{min}$

HEAD: 4 atm (60 psig)

FLOWMETER: ORIFICE

FLOW CONTROL VOLUME: HAMMEL DAHL DIAPHRAM

CONTROL VALVE OR

EQUIVALENT

TANK MATERIAL THICKNESS: $0.64 \mathrm{~cm}$ (1/4 in.)

FIGURE 9. Calciner Condensate Tank 


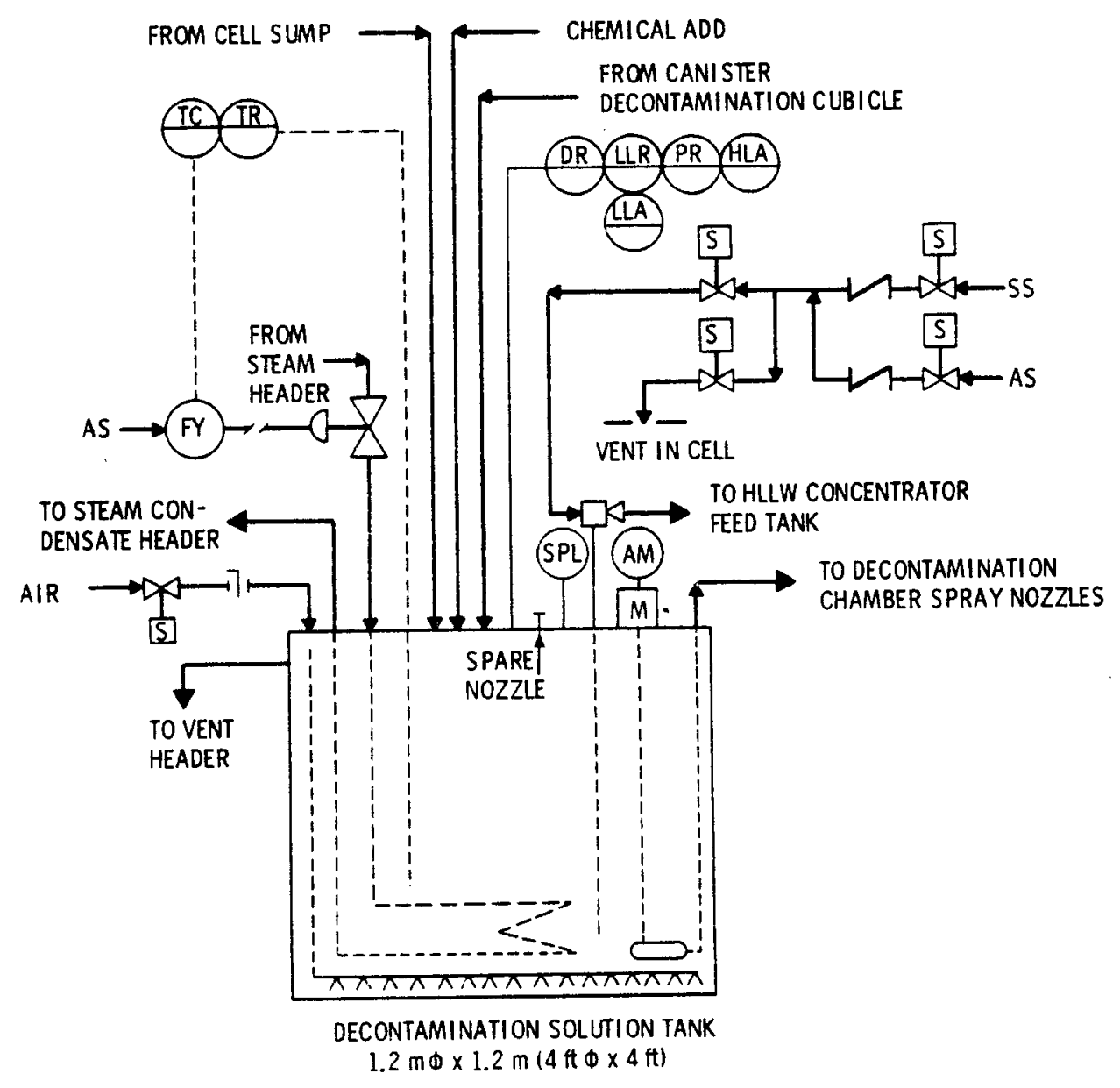

OPERATING CONDITIONS

VOLUME: $1135 \ell(300 \mathrm{GAL})$

PRESSURE: $0.97 \mathrm{~atm}$

TEMPERATURE: $50^{\circ} \mathrm{C}$

DECONTAMINATION SOLUTION FLOW RATE: $100 \mathrm{l} / \mathrm{min}$

DESIGN PARAMETERS

VOLUME: $1420 \ell(375 \mathrm{GAL})$

PRESSURE: $0.5-1.5 \mathrm{~atm}$

TEMPERATURE: $0-110^{\circ} \mathrm{C}$

HEATING: $100 \mathrm{~kW}$
DECONTAMINATION SOLUTION

FLOW RATE: $20-200 \ell / \mathrm{min}$

AGITATION: AIR SPARGE RING

TRANSER JET CAPACITY (TYPE-STEAM):

$\sim 100 \mathrm{e} / \mathrm{min}(25 \mathrm{gpm})$

MATERIAL: $304-$ STAINLESS STEEL

NOTES:

DECONTAMINATION SOLUTION PUMP SYSTEM

PUMP: TYPE: CENTRIFUGAL

CAPACITY: $200 \mathrm{e} / \mathrm{min}$

HEAD: $4.8 \mathrm{~atm}(70 \mathrm{psig})$

FLOWMETER: NONE

FLOW CONTROL: NONE

FIGURE 10. Decontamination Solution Tank 


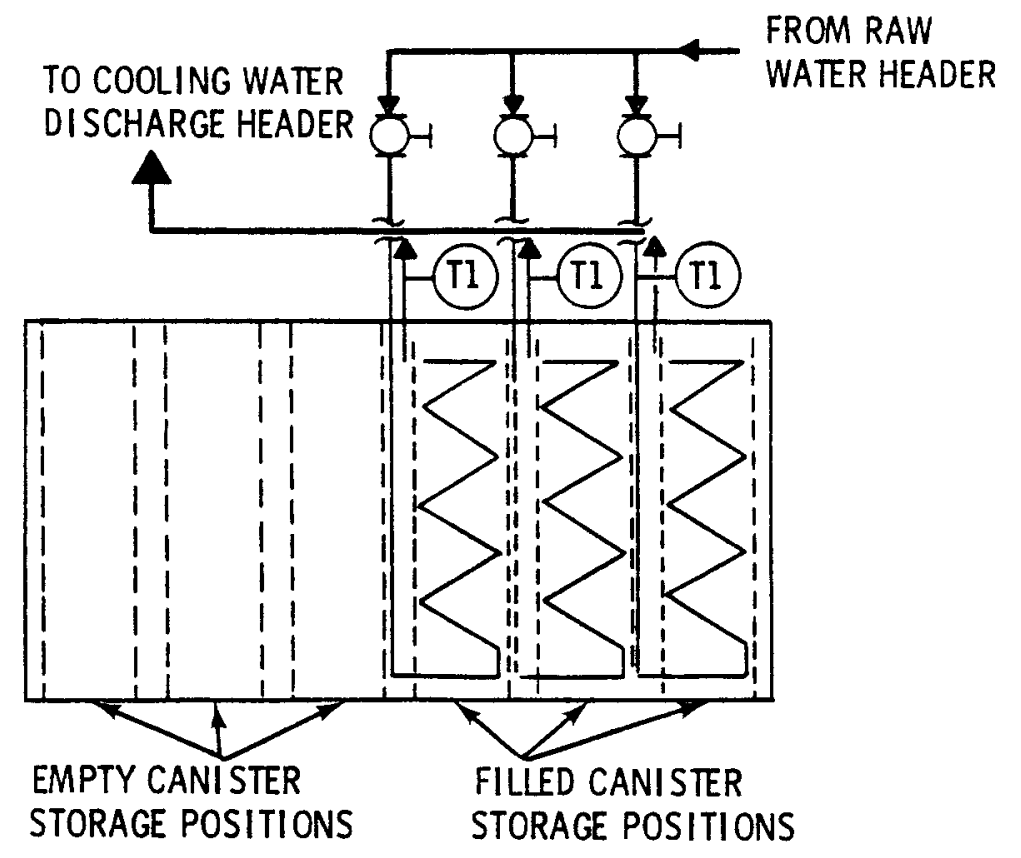

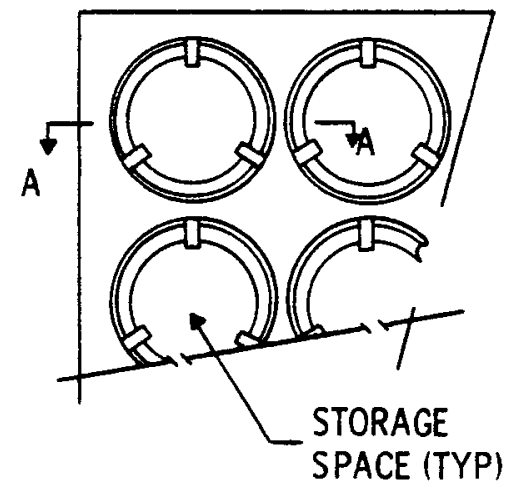

CUT-AWAY PLAN VIEW

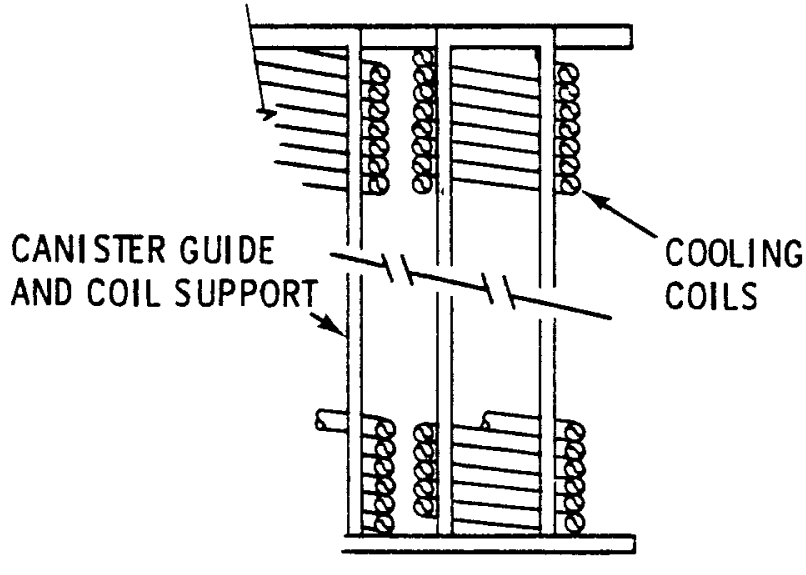

SECTION - AA
TYPE: OPEN WELDED FRAME

CAPACITY: THREE EMPTY CANISTERS THREE FULL CANISTERS

MATERIAL: $304 t$ SS
COOLING: WRAPPED $304 \_$SS TUBING

(A TUBE COIL IS PLACED OUTSIDE OF CANISTER GUIDES IN STORAGE POSITION) COOLING CAPACITY: $50 \mathrm{~kW} / \mathrm{COIL}$ RACK DIMENSIONS: ( $6 \mathrm{ft} \times 6 \mathrm{ft} \times 11 \mathrm{ft}$ )

FIGURE 11. Canister Storage Rack 


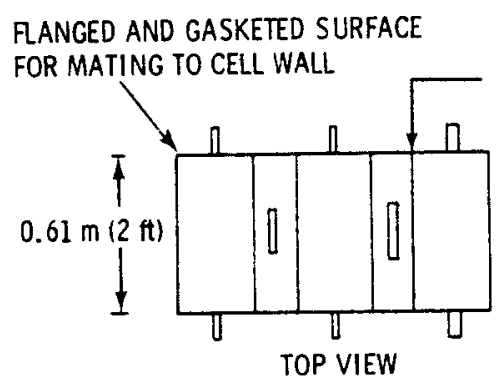

FILTER HOLDER FRAME IGASKETED AND

BOLTED FLANGES ON THE FILTER

HOUSING STRUCTURE TYP.)

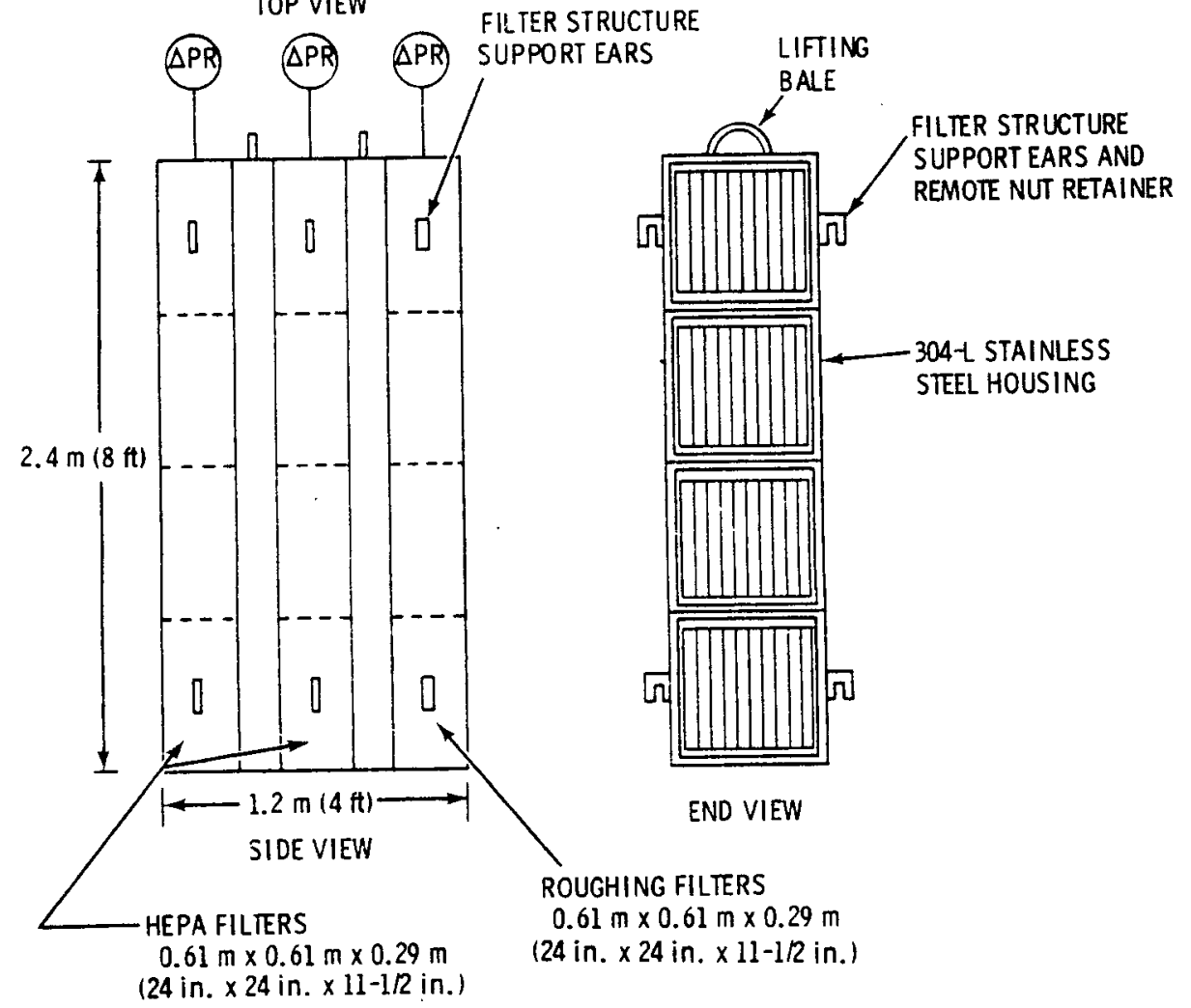

OPERATING CONOITIONS

AIR FLOW RATE: $113 \mathrm{~m}^{3} / \mathrm{min}$ (4000 cfm) PER ASSEMBLY

TEMPERATURE: $\sim 65^{\circ} \mathrm{C}$

PRESSURE: $\sim 1 \mathrm{~atm}$

HUMIDITY: $\leq 30 \%$ RELATIVE

DESIGN PARAMETERS.

CAPACITY (2 ASSEMBLIES): $226 \mathrm{~m}^{3} / \mathrm{min}$ (8000 cfm)

TEMPERATURE: $\leq 100^{\circ} \mathrm{C}$

PRESSURE: $\sim 1 \mathrm{~atm}$
FILTERS:

CAPACITY: $28 \mathrm{~m}^{3} / \mathrm{min}(1000 \mathrm{cfm})$

DIMENSIONS: $0.61 \mathrm{~m} \times 0.61 \mathrm{~m} \times 0.29 \mathrm{~m}$ (24 in. $x 24$ in. $x 11.5$ in.)

FRAME: FIRE RETARDENT WOOD

HOUSING: 304-L STAINLESS STEEL

TESTING: AN IN-PLACE FILTER TEST CAPABILITY WILL BE SUPPLIED WITH THE ASSEMBLY

FIGURE 12. Cell Air Filters 


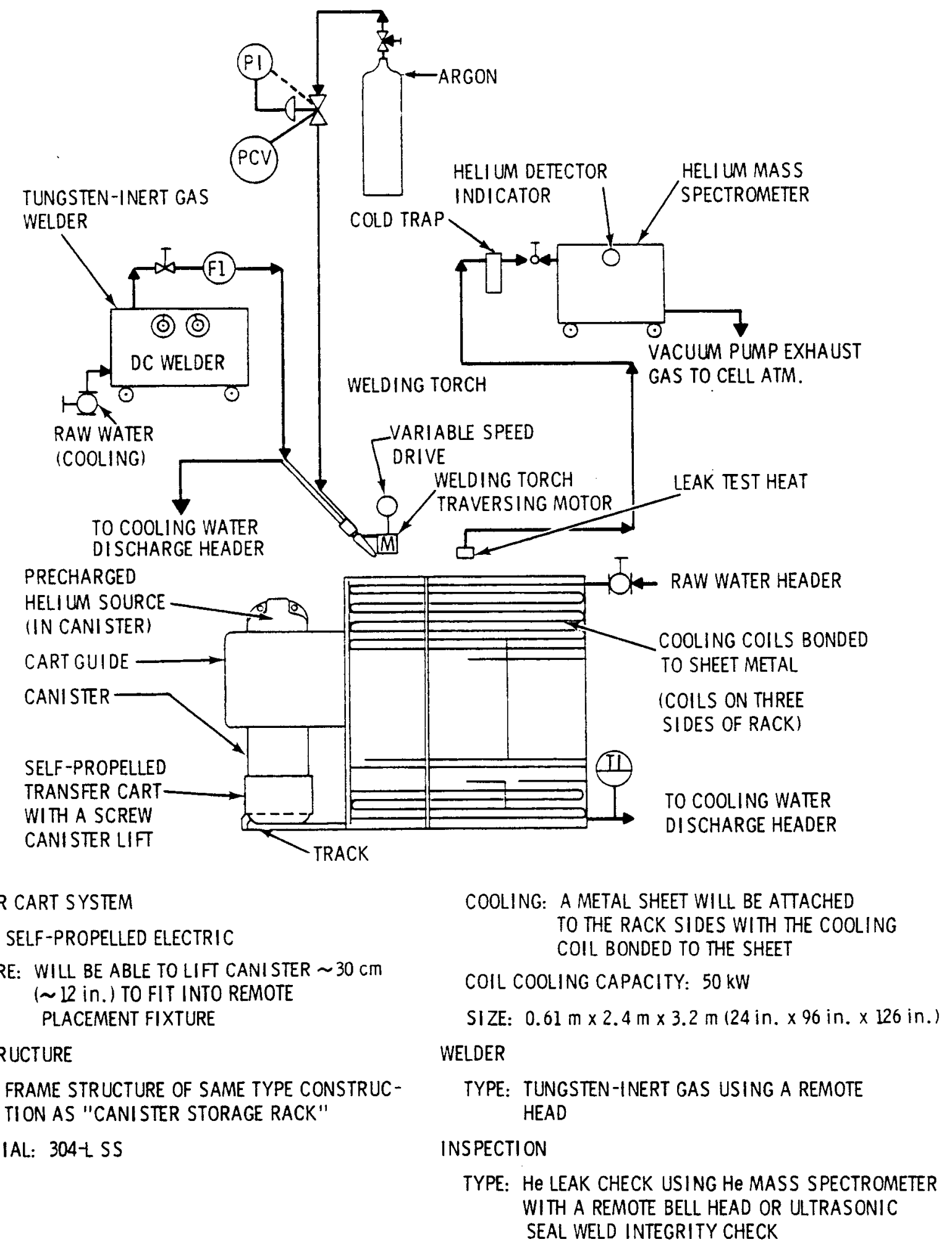

FIGURE 13. Welding and Inspection Stations 


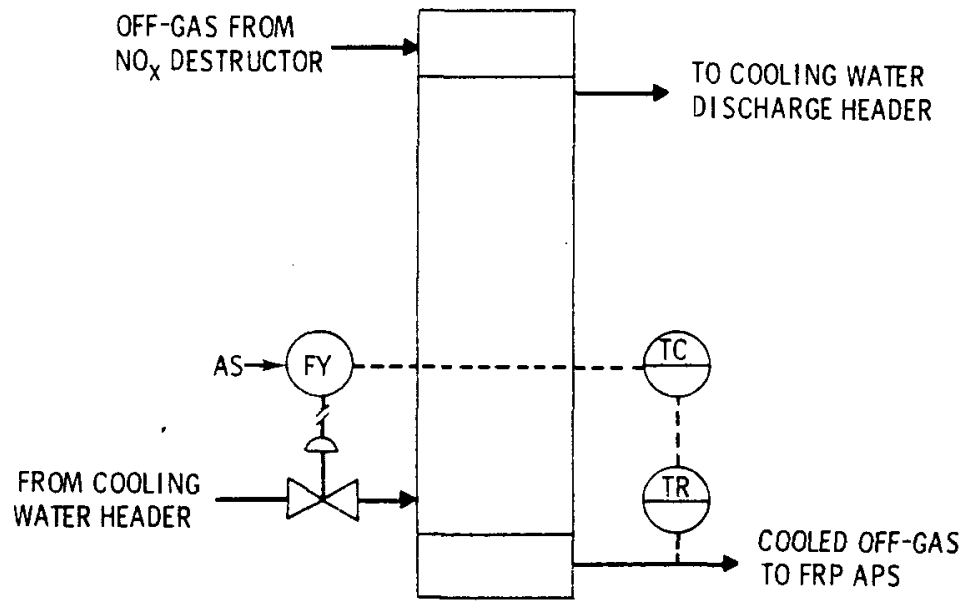

OPERATING CONDITIONS

CAPACITY: $\sim 100,000 \mathrm{~g}$-moles OF GAS TTABLE 1, 12, OFF-GAS TO FRPI PER DAY AT $\sim 5000^{\circ} \mathrm{C}$ IS COOLED TO $\sim 550 \mathrm{~F}$

TEMPERATURE (OFF-GAS): SEE ABOVE

PRESSURE: $\sim 0.95 \mathrm{~atm}$

DESIGN PARAMETERS

CAPACITY: FROM 0-200.000 g-moles OF GAS (TABLE 1, 12. OFF-GAS TO FRPI PER DAY AT $\sim 500^{\circ} \mathrm{C}$ IS COOLED TO $\sim 55^{\circ} \mathrm{C}$

TYPE: SHELL-TUBE SINGLE PASS

BAFFLED

ROATING HEAD

AIR ON TUBE SIDE

WATER ON SHELL SIDE

HEAT TRANSFER AREA: $\sim 11 \mathrm{~m}^{2}\left(\sim 120 \mathrm{ft}^{2}\right)$

HEAD LOAD: $\sim 21 \mathrm{~kW}(\sim 72,000 \mathrm{Btu} / \mathrm{hr})$

MATERIAL: $304-$ STAINLESS STEEL

FIGURE 14. Calciner Condenser 


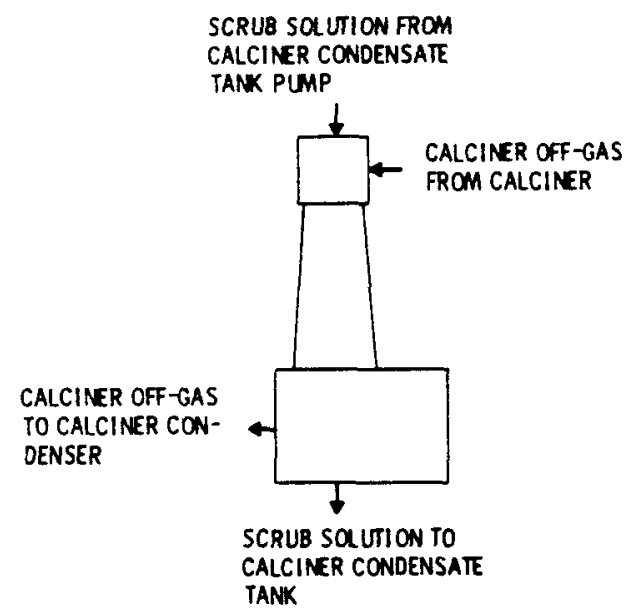

\section{OPERATING CONDITIONS}

CAPACITY: $\$ 250$ sto $2 \mathrm{~m}$ in (150 SCFM) OF CALCINDER OFF GAS (TABLE 1. (4) CALC INDER OFF-GAS) AT $\leq 350^{\circ} \mathrm{C}$ COOLED TO $\leq 110^{\circ} \mathrm{C}$

PRESSURE (CALCINER OFF-GAS): $\sim 0.97 \mathrm{~atm}$

\section{DESIGN PARAMETERS}

TYPE: VENTURI SCRUBBER-SEPARATOR

CAPACITY: $6370 \mathrm{std} \ell \mathrm{m}$ in (300 SCFM) OF CALC INOER OFF-GAS (table 1, (4) CALCINDER OFF-GAS) AT $\triangle 350^{\circ} \mathrm{C}$ COOLED TO $\leq 110^{\circ} \mathrm{C}$

TEMPERATURE: $0-400^{\circ} \mathrm{C}$

PRESSURE (CALCINER OFF-GAS): $0.5-1.2 \mathrm{~atm}$

MATERIAL: 304- STAINLESS STEEL

NOTE: THE FOLLWING SYSTEM, EQUIVALENT, OR BETIER CAN BE CONSIOERED FOR DESIGN PURPOSES.
S\&K TYPE TOI4 SCRUBBER-SEPARATOR SYSTEM. THE FQLLWING COMPONENTS WILL BE SUPPLIED:

1. EJECTOR-VENTURI SCRUBBER, TYPE 7010, $15 \mathrm{~cm}(6 \mathrm{in}, 1316$ STAINLESS STEEL. THE SCRUBBER WILL HAVE A $3.2 \mathrm{~cm}(1-1 / 4$ in $)$ (EXTRA LARGE) 316 STAINLESS STEEL FIG. 622 I SPRAY NOZZLE AND 316 STAINLESS STEEL SPIRAL.

1. SEPARATOR, TYPE 7D40, $15 \mathrm{~cm}$ (6 in.) 316 STAINLESS STEEL, THE SEPARATOR WILL HAVE AN SK DESIGNED IMPACT BAFFE SEPARATOR ELEMENT

PERFORMANCE: THE $15 \mathrm{~cm}$ (6 in.) TYPE 7014 SCRUBBER-SEPARATOR SYSTEM IS DESIGNED TO HANOLE $15.6 \mathrm{~m}^{3} / \mathrm{min}$ (500 ACFM) OF GAS AT $400^{\circ} \mathrm{C}$. (25 in W.C.)

0.061 atm $14 \mathrm{~m}^{3} \mathrm{~min}$ VACUUM, CONSISTING OF $14 \mathrm{~m}^{3} 500 \mathrm{Ctm}$ OF STEAM WITH NITRIC ACID AND 0.26 G F/DCFM. WHEN THE SPRAY NOZZLE IS SUPPLIED WITH $180 / \mathrm{min} 48 \mathrm{gpm}$ OF FRESH WATER AT $29^{\circ} \mathrm{C}\left(85^{\circ} \mathrm{F}\right)$ AT $4.1 \mathrm{~atm}$ (60 psig) PRESSURE, THE SCRUBBER-

SEPARATOR SYSTEM WILL HAVE A $0.012 \mathrm{~atm}, 5$ in. W.C. DRAFT. AT THESE OPERATING CONDITIONS THE SCRUBBER -SEPARATOR SYSTEM WILL CONOENSE AND COOL THE GAS TO LESS THAN $60^{\circ} \mathrm{C}$ (14007) AND REMOVE $90 \%$ of 1 MICRON SIZI PARTICLES.

THE EJECTOR VENTURI MAY BE CHANGED TO A HIGH ENERGY VENTURI TO ACHIEVE A MORE EFFICIENT SCRUBBING SYSTEM.

\section{FIGURE 15. Calciner Scrubber-Separator}




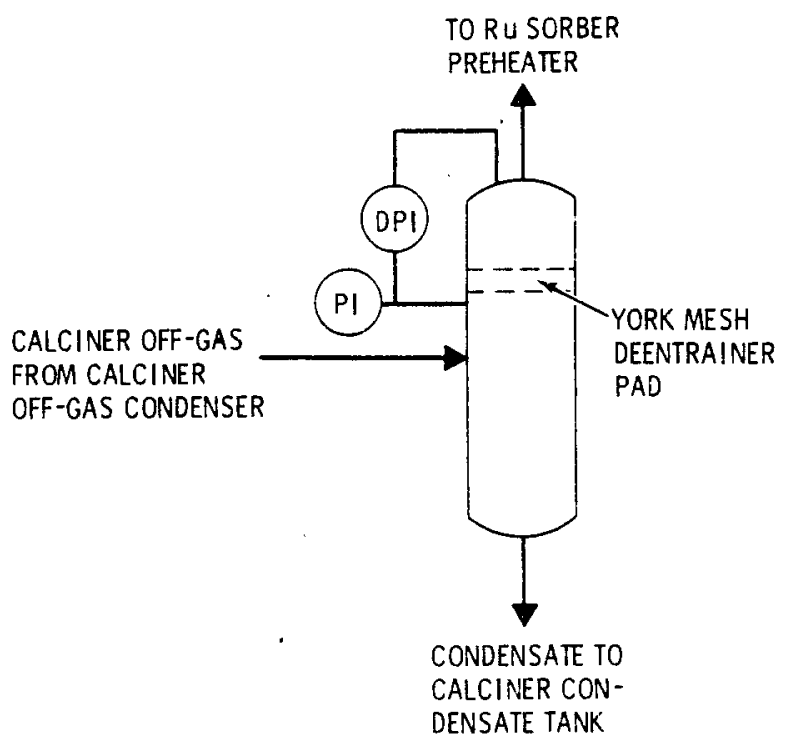

OPERATING CONDITIONS

CAPACITY: $57.4 \mathrm{cfm}(1625 \mathrm{\ell} / \mathrm{min})$ OF CONDENSER OFF-GAS (TABLE 1, (6) CONDENSER OFF-GAS)

TEMPERATURE: $\sim 50^{\circ} \mathrm{C}$

PRESSURE: $\sim 0.95 \mathrm{~atm}$

DESIGN PARAMETERS

TYPE: YORK MESH DEENTRAINER IN-PIPE OR EQUIVALENT

CAPACITY: $2435 / \mathrm{min}(\leq 86.1 \mathrm{cfm})$ OF VAPOR SATURATED AIR @ $\angle 50^{\circ} \mathrm{C}$,

ENTRAINED LIQUID 2.2 $\mathrm{MHNO}_{3}$. AND AIR WILL CONTAIN SOME NO $\mathrm{X}$

ENTRAINMENT LOAD = UNKNOWN

MATERIAL: $304-\mathrm{L}$ STAINLESS STEEL
NOTE:

DEMISTER: TYPICAL DESIGN

AT $2435 \mathrm{~min}(86.1 \mathrm{cf} \mathrm{m}) \leq 050^{\circ} \mathrm{C}$ WANT LINEAR FLOW RATE $\leq 4.5 \mathrm{~m} / \mathrm{sec}(15 \mathrm{ft} / \mathrm{sec})$ $10 \mathrm{~cm}$ ( 4 in.) THICK YORK MESH DEMISTER EFFECTIVE AREA $=75.5 \mathrm{~cm}^{2}\left(0.081 \mathrm{ft}^{2}=11.7 \mathrm{in} .{ }^{2}\right)$ EFFECTIVE DIAMETER $=10 \mathrm{~cm}$ ( $3.9 \mathrm{in.})$

PIPE ID $=10 \mathrm{~cm}$ ( 4 in.)

PIPE THICKNESS $\approx 0.64 \mathrm{~cm}(1 / 4 \mathrm{in}$.

MESH SUPPORT - WELDED IN ANNULAR PLATES

TOTAL HEIGHT $\leq 30 \mathrm{~cm}$ ( $1 \mathrm{ft}$ ) (EXCL. CONNECTOR HEADS)

MESH $\triangle P \leq 0.0037 \mathrm{~atm}\left(1.5 \mathrm{in} . \mathrm{H}_{2} \mathrm{O}\right)$

FIGURE 16. Off-Gas Demister 


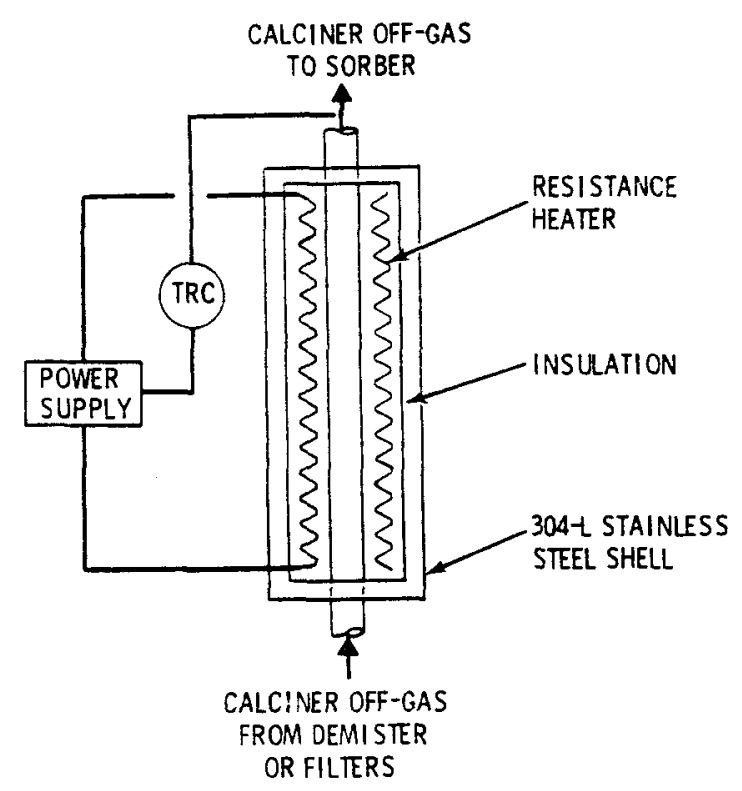

OPERATING CONDITIONS

CAPACITY: 1375 std/min (48.5 SCFM OF DEMISTER)-GAS OFF-GAS (TABLE - 1 . (T) DEMINSTER OFF-GAS) AT $\leq 80^{\circ} \mathrm{C}$ ARE HEATED $\leq 60^{\circ} \mathrm{C}$

TEMPERATURE (OFF-GAS)

$$
\begin{array}{ll}
\frac{\text { INLET }}{\leq 80^{\circ} \mathrm{C}} & \frac{\text { EXIT }}{\leq 130^{\circ} \mathrm{C}} \\
\leq 50^{\circ} \mathrm{C} & \sim 80^{\circ} \mathrm{C}
\end{array}
$$

PRESSURE (OFF-GAS) $\sim 0.95 \mathrm{~atm}$

\section{DESIGN PARAMETERS}

CAPACITY: $\sim 0-3 \mathrm{~kW}$

TYPE: ELECTRICAL RESISTANCE

TEMPERATURE: $0-200^{\circ} \mathrm{C}$

PRESSURE: $0.5-1.5 \mathrm{~atm}$

MATERIAL: $304-\mathrm{L}$ STAINLESS STEEL EXCEPT FOR HEATING ELEMENTS AND INSULATION AND OTHER ITEMS AS MAY BE APPROPRIATE

NOTE: FOR PRELIMINARY DESIGN ASSUME $\sim 0.37 \mathrm{~m}^{2}\left(\sim 4 \mathrm{~m}^{2}\right)$ OF HEAT TRANSFER AREA IS NEEDED AND THIS IS SUPPLIED BY $5 \mathrm{~cm}(2 \mathrm{in}$.) DIAMETER PIPE THAT IS $2.4 \mathrm{~m}$ (8 ft) LONG.

THE HEATING ELEMENT SUPPORT STRUCTURE AND INSULATION ARE PLACED IN A $15 \mathrm{~cm} 16$ in. I PIPE.

FIGURE 17. I and Ru Sorber Feed Heaters 


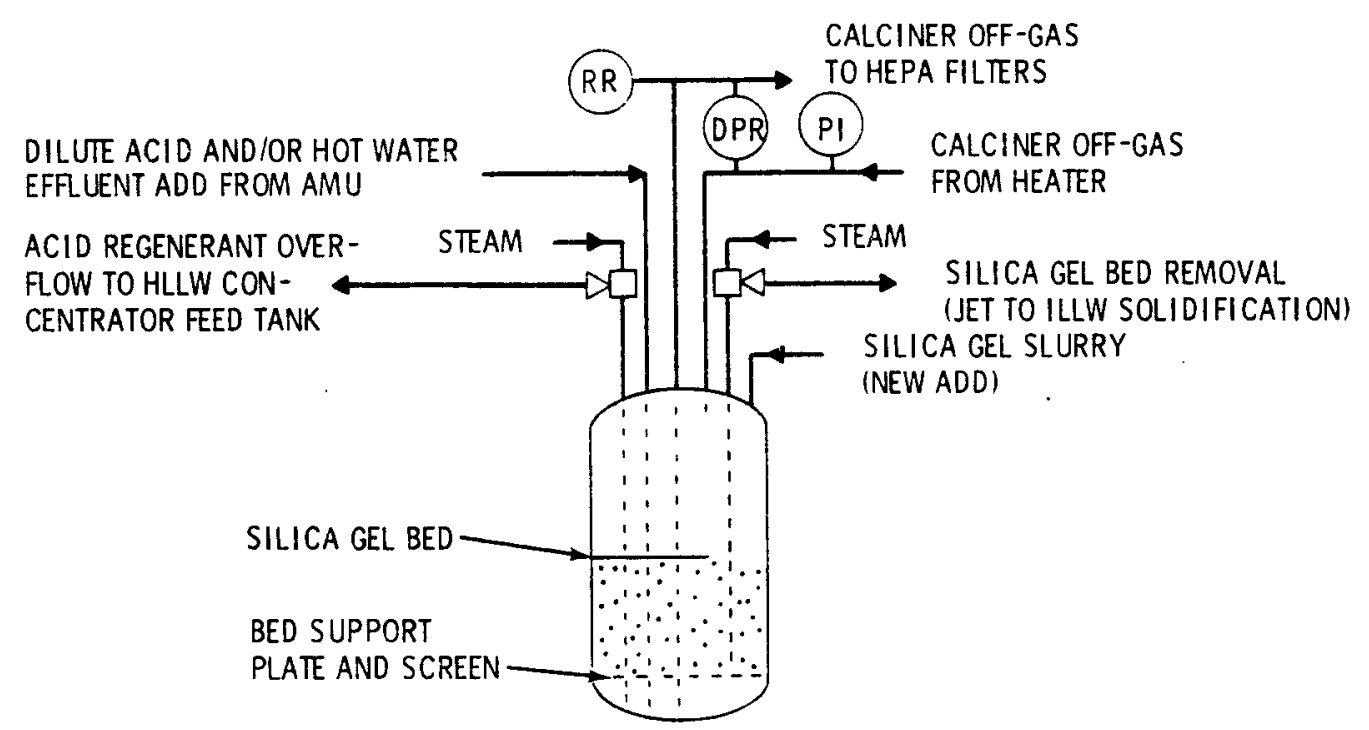

\section{OPERATING CONDITIONS}

CAPACITY (AIR HANDLING):

1375 std $\ell / m i n$ (48.5 SCFM) OF DEMINSTER OF GAS (TABLE-1, (7) DEMISTER OFF-GAS)

TEMPERATURE (OFF-GAS): $80^{\circ} \mathrm{C}$

PRESSURE: $\sim 0.95 \mathrm{~atm}$

\section{DESIGN PARAMETERS}

CAPACITY (AIR HANDLING):

2070 std $\ell / m i n$ (73 SCFM) OF DEMISTER OFF-GAS

(TABLE-1, (7) DEMISTER OFF-GAS)

TEMPERATURE: $0-150^{\circ} \mathrm{C}$

PRESSURE: $0.5-1.5 \mathrm{~atm}$

TYPE: PACKED SILICA GEL BED

MATERIALS: VESSEL - 304- SS

$$
\text { BED - 12-40 MESH }
$$

VESSEL SIZE: $\begin{aligned} & 66.5 \mathrm{~cm}(26.2 \mathrm{in.}) 1 \mathrm{D} \\ & 1.8 \mathrm{~m}(70 \mathrm{in.}) \mathrm{HEIGHT}\end{aligned}$

THICKNESS: $0.64 \mathrm{~cm}(0.25 \mathrm{in}$.)

BED SUPPORT: $0.48 \mathrm{~cm}(3 / 16 \mathrm{in}$.$) 304-L SS PLATE$ DRILLED FULL OF $0.64 \mathrm{~cm}(0.25 \mathrm{in}$.) HOLES SUPPORTING A 304-L SS HEAVY SCREEN WHICH IS $\leq 80$ MESH

HEADS: STANDARD DISHED

BED: DAVIDSON GRADE 40 SILICA GEL OR EQUIVALENT

SIZZ: $41 \mathrm{~cm}$ (16.2 in.) dia $76 \mathrm{~cm}$ (30 in.) DEPTH

PARTICLE SIZE: 12-40 MESH

JETS (TYPE -STEAM): $\sim 100 \ell / \mathrm{min}$ ( $25 \mathrm{gpm}$ )

FIGURE 18. Ruthenium Sorber 


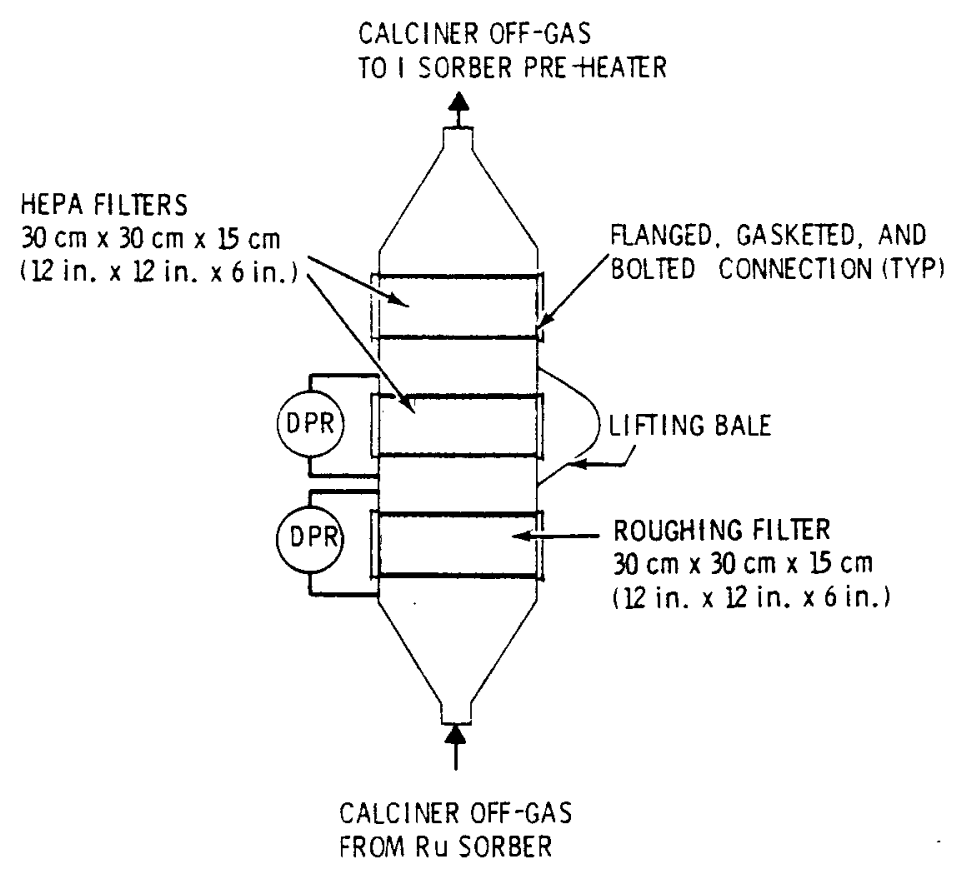

OPERATING CONDITIONS

CAPACITY: 1375 std $\ell / \min$ (48.5 SCFM) OF RU SORBER OFF-GAS (TABLE 1. (8) RL SORBER OFF-GAS)

TEMPERATURE: $\leq 80^{\circ} \mathrm{C}$

PRESSURE: $\sim 0.95$

DESIGN PARAMETERS

CAPACITY: $3580 \mathrm{std} \ell / \min$ (125 SCFM)

TEMPERATURE: $0-150^{\circ} \mathrm{C}$

PRESSURE: $\sim 0.95 \mathrm{~atm}$
TYPE: CUSTOM FILTER ASSEMBLY

MATERIALS: FILTER CASE: 304- SS AND FLANGES

GASKETS: ASBESTOS OR SILICONE

FILTERS: STANDARD HEPA AND PRE FILTERS WITH FIRE RESISTENT CASE

DIMENSIONS: $\sim 35 \mathrm{~cm} \times 35 \mathrm{~cm} \times 1.5 \mathrm{~m}$

$$
(\sim 14 \text { in. } \times 14 \text { in. } \times 60 \mathrm{in} .)
$$

FIGURE 19. Pre- and HEPA Off-Gas Filters 


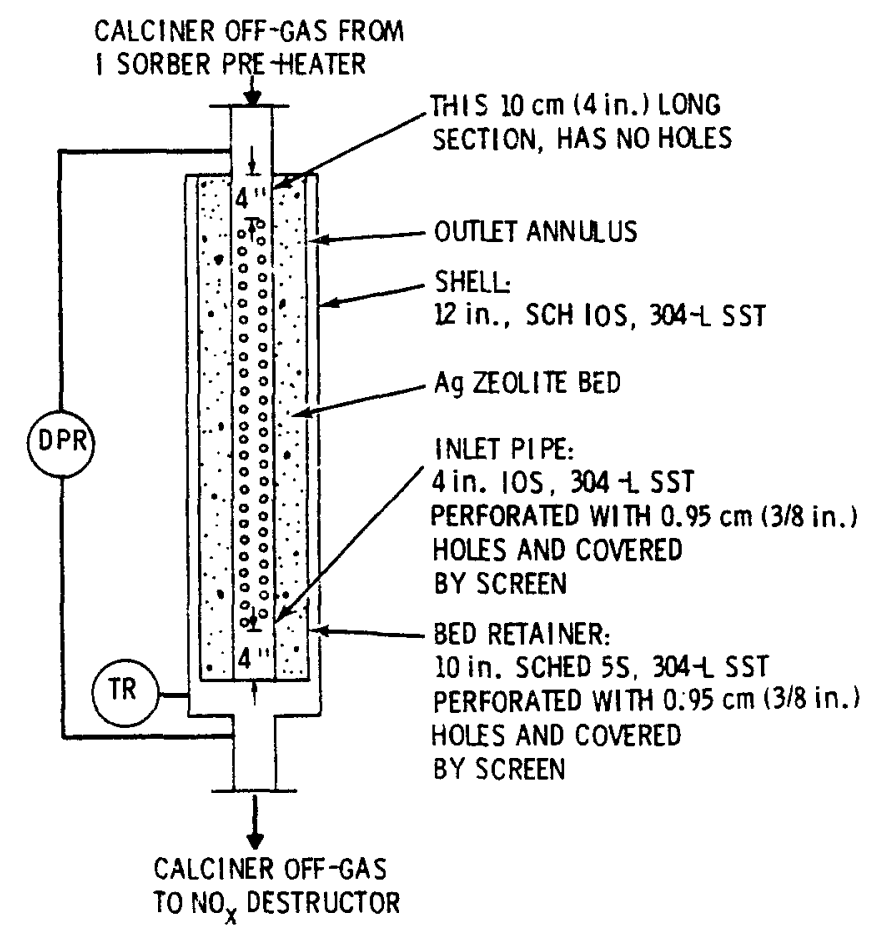

\section{OPERATING CONDITIONS}

CAPACITY: 1375 std $\ell / \min$ (48 SCFM) OF FILTERED OFF-GAS (TABLE L, (9) FILTERED OFF-GAS)

TEMPERATURE: $130^{\circ} \mathrm{C}$

PRESSURE: $\sim 0.95 \mathrm{~atm}$

\section{DESIGN PARAMETERS}

CAPACITY: 2070 std $l / \min$ (73 SCFM) OF FILTERED

OFF-GAS (TABLE 1, (9) FILTERED OFF-GAS

TEMPERATURE: $0-200^{\circ} \mathrm{C}$

PRESSURE: $0.5-1.5 \mathrm{~atm}$

TYPE: CUSTOM ANNULAR SORBER BED
MATERIALS: VESSEL: $304-$ SS

BED: 12-14 MESH SILVER ZEOLITE GRANULES

VESSEL: CONCENTRIC ANNULI CONSTRUCTION

SI ZE: $32 \mathrm{~cm} \Phi \times 1.5 \mathrm{~m}(12-3 / 4 \mathrm{in} . \Phi \times 5 \mathrm{ft})$

END PLATES: $0.64 \mathrm{~cm}(0.25 \mathrm{in}$.) (BED AND VESSEL)

SCREEN: HEAVY, $30 \mathrm{MESH}$

BED: LINDE I3X ZEOLITE IN AG FORM

ANNUL US BED DIMENSIONS

$I D=11.4 \mathrm{~cm}(4.5 \mathrm{in}$.

$\mathrm{OD}=26.5 \mathrm{~cm}(10.4 \mathrm{in}$.

DEPTH $=1.36 \mathrm{~m}(4.5 \mathrm{ft})$

MESH $=12-14$

FIGURE 20. Iodine Sorber 


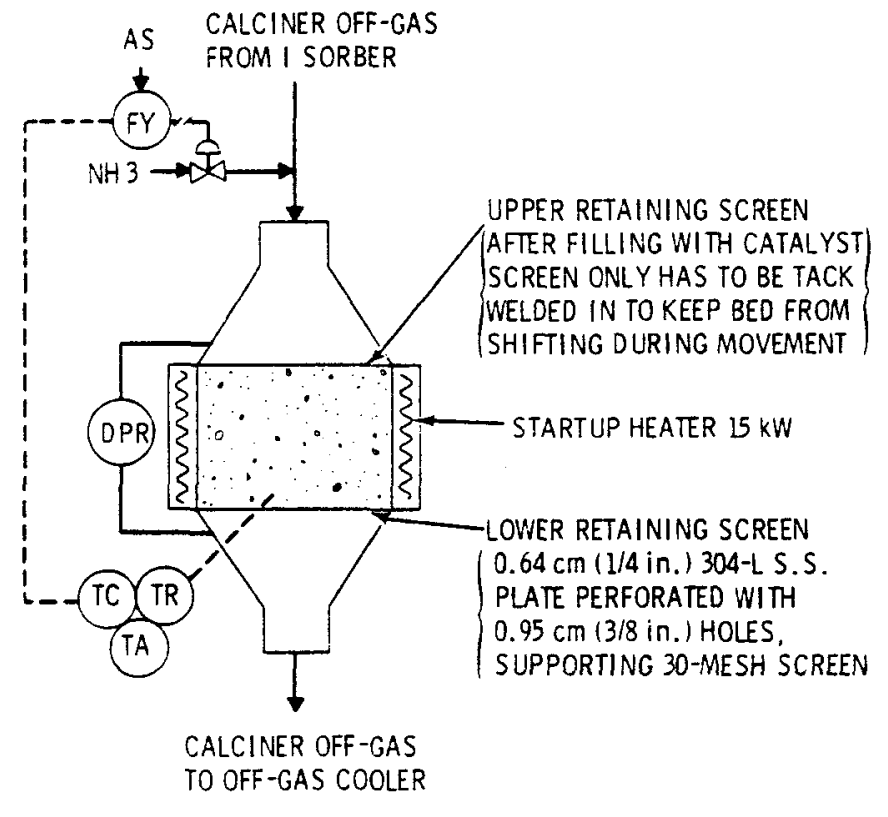

OPERATING CONDITIONS

SEE TABLE 1, MATERIAL BALANCE

DESIGN PARAMETERS

OPERATING PARAMETERS: SEE TABLE 1

TYPE: CUSTOM DESIGN CYLINDRICAL BED REACTOR

MATERIAL: VESSEL: $304-L$ SS, $0.64 \mathrm{~cm}$ (1/4 in.) THICK

BED: $0.16 \mathrm{~cm}$ (1/16 in.) ZEOLON 900

EXTRUDATE PELLETS
VESSEL: CYLINDRICAL WITH TAPER CONE ENDS

SIZE: $0.3 \mathrm{~m} \Phi \times 0.91 \mathrm{~m}(12 \mathrm{in} . \Phi \times 3 \mathrm{ft})$

BED: $0.16 \mathrm{~cm}(1.16 \mathrm{in}$.) EXTRUDATE ZEOLON 900

SIZE: $20 \mathrm{~cm}(8 \mathrm{in}$. I DEEP

$30 \mathrm{~cm}$ ( 12 in.) DIAMETER

HEATER: $\quad 15 \mathrm{~kW}$ RESISTANCE HEATER USED FOR STARTUP INSULATED OUTSIDE OF ELEMENTS

HEATER COVERED WITH 304-L SHELL

FIGURE 21. $\quad \mathrm{NO}_{\mathrm{x}}$ Destructor 


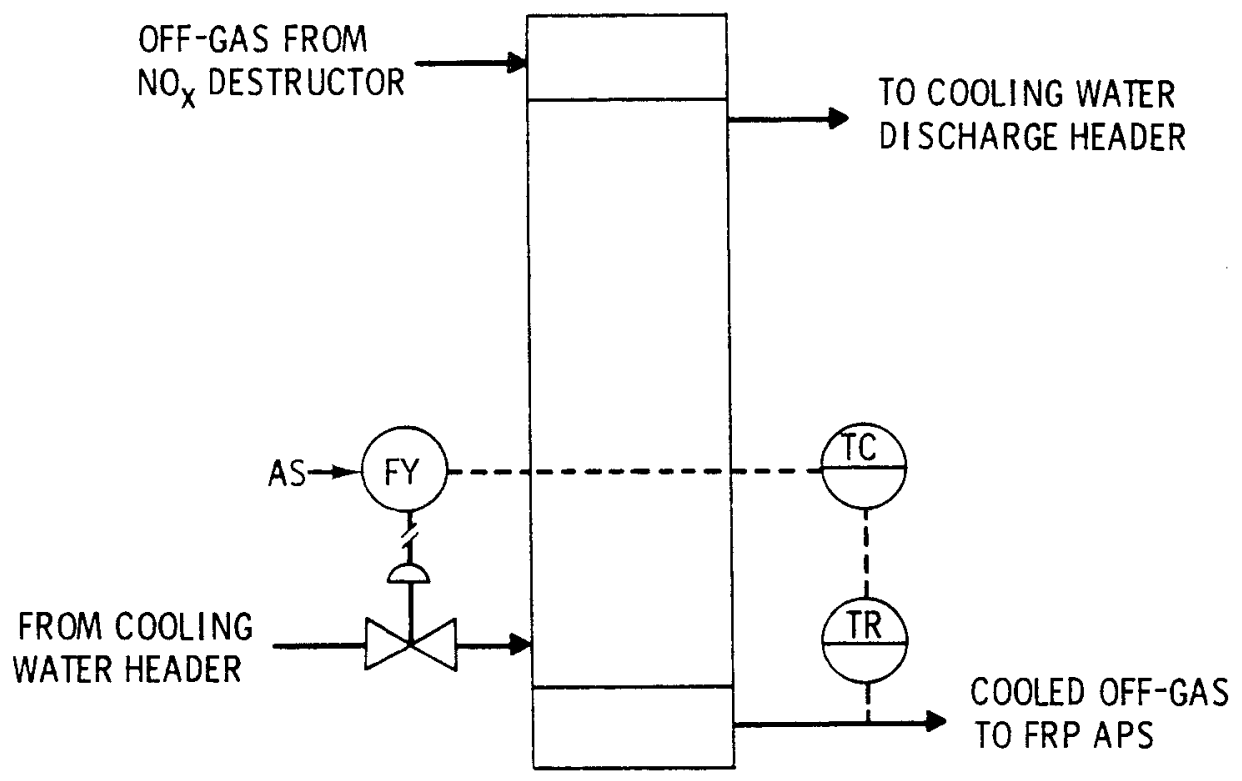

\section{OPERATING CONDITIONS}

CAPACITY: $\sim 100,000 \mathrm{~g}$-moles OF GAS (TABLE 2, 12. OFF-GAS TO FRP) PER DAY AT $\sim 500^{\circ} \mathrm{C}$ IS COOLED TO $\sim 550 \mathrm{~F}$

TEMPERATURE (OFF-GAS): SEE ABOVE

PRESSURE: $\sim 0.95 \mathrm{~atm}$

DESIGN PARAMETERS

CAPACITY: FROM 0-200.000 g-moles OF GAS (TABLE 2, 12. OFF-GAS TO FRPI PER DAY AT $\sim 500^{\circ} \mathrm{C}$ IS COOLED TO $\sim 55^{\circ} \mathrm{C}$
TYPE: $\quad$ SHELL-TUBE

SINGLE PASS

BAFFLED

FLOATING HEAD

AIR ON TUBE SIDE

WATER ON SHELL SIDE

HEAT TRANSFER AREA: $\sim 11 \mathrm{~m}^{2}\left(\sim 120 \mathrm{ft}^{2}\right)$

HEAD LOAD: $\sim 21 \mathrm{~kW}(\sim 72,000 \mathrm{btu} / \mathrm{hr})$

MATERIAL: $304-\mathrm{L}$ STAINLESS STEEL

FIGURE 22. Off-Gas Cooler 
filters, the contamination of the equipment located out of the WVC will be less than that of equipment pieces located further upstream.

Much additional nonprocess equipment will be required to operate the waste vitrification process, including:

- Remote-operated bridge crane

Number: 1

Capacity: 7.5 Tons

Number of Remote Operating Stations: 4

- Master-Slave Manipulators

Number: Up to 3 pair

Model: To be determined, but will be heavy duty, able to lift up to $23 \mathrm{~kg}(50 \mathrm{lb})$, and to perform limited maintenance operations

- Periscopes

Number: Up to 3

Model: To be determined

- Prepackaged Helium Sources

Number: 1 per canister

Type: Steel sponge filled with liquid helium

- Helium Source Wall Pass-Through Mechanism

Number: 1

Type: To be designed.

UTILITIES, MATERIALS AND WASTES

Utilities required to operate the NWVF, the design load, and the average consumption rate are indicated in Table 9. Only utilities used in the NWVF and provided from the FRP are shown in Table 9. Any emergency utilities required, such as electricity and cooling water, will be supplied from the FRP emergency services.

Essential materials used in NWVF operations and their average consumption rates are also shown in Table 9. Maintenance and replacement materials are not shown. Only chemicals used for periodic facility decontamination and cleanup are included in Table 9. 


\section{TABLE 9. Nuclear Waste Vitrification Facility Utilities and Essential Material Requirements}

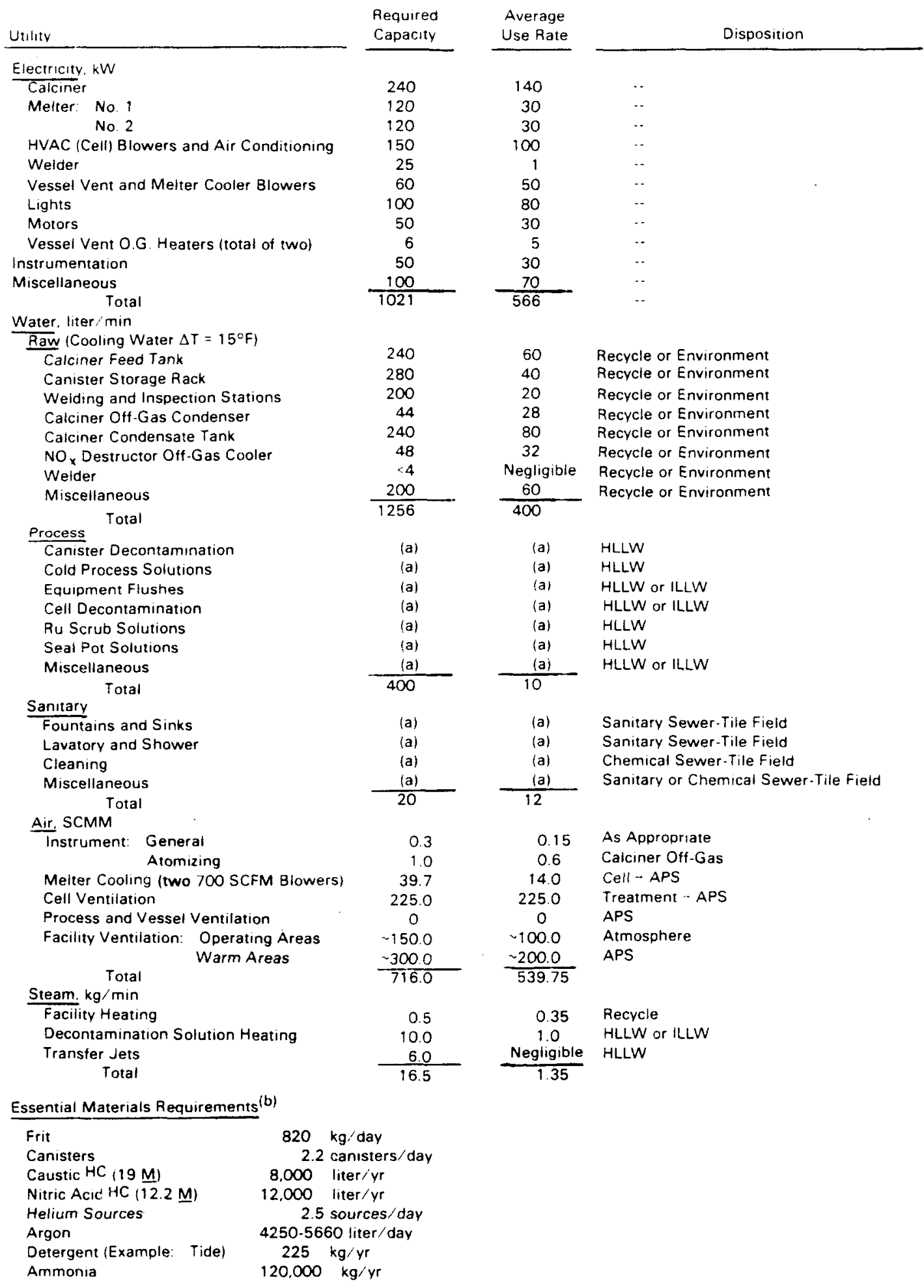

(a) No breakdown

(b) Exciudes maintenance materials and apparel 
There are a variety of wastes generated from NWVF operation, maintenance, and shutdown activities. The waste types and their dispositions, characteristics, and average generation rates are estimated in Table 10. Particulates contained in gaseous effluents are assumed to be calcine. The physical properties of the calcine particulates are shown in Figure 23.

The estimates in Tables 9 and 10 are based on engineering calculations and operations of similar facilities.

The facility will handle toxic materials and/or materials that present other (chemical or radioactive) hazards. These materials are identified in Tables 9 and 10 by a superscript " $H$ ". If chemical, a "C" follows the "H"; if radioactive, an "R" follows the "H"; and if both, a "CR" follows the "H". 


\section{TABLE 10. Nuclear Waste Vitrification Facility Waste Generation}

\begin{tabular}{|c|c|c|c|c|}
\hline \multirow[b]{2}{*}{ RADIOACTIVEHR } & \multirow[t]{2}{*}{$M^{3} / y r$} & \multirow[t]{2}{*}{$\begin{array}{c}\text { Activity } \\
\mathrm{Ci} / \mathrm{yr} \text {. Type }\end{array}$} & $\begin{array}{l}\text { Disposal } \\
\text { Method }\end{array}$ & \multirow[t]{2}{*}{ Characterization } \\
\hline & & & & \\
\hline \multicolumn{5}{|l|}{ Liquids } \\
\hline Canister Decontamination & & MFP(a) & HLLW & Water \\
\hline Cell \& Equipment Decontamination & & MFP & HLLW \& ILLW & $\begin{array}{l}\text { Water, } \mathrm{HNO}_{3}, \mathrm{NaOH} \text {, Detergent, } \\
\text { Complexant }\end{array}$ \\
\hline $\begin{array}{l}\text { Calciner Off-Gas Condensate } \\
\text { Ru Scrubber Regeneration Solution } \\
\text { Miscellaneous }\end{array}$ & $3 E 3$ & $\begin{array}{l}\text { 1E5, MFP } \\
\text {, Ru(b) } \\
\text { MFP }\end{array}$ & $\begin{array}{l}\text { HLLW } \\
\text { HLLW } \\
\text { HLLW \& ILLW }\end{array}$ & $\begin{array}{l}\text { Table } 1,(2) \text { Calciner Condensate } \\
\text { Hot Water or } 0.1 \mathrm{M} \mathrm{HNO} \\
\text { Water, } \mathrm{HNO}_{3}, \mathrm{NaOH}\end{array}$ \\
\hline \multicolumn{5}{|l|}{ Gases } \\
\hline Process Off-Gas & $1 \mathrm{E} 5$ & 3, MFP & APS & $\begin{array}{l}\text { Table 1, (12) Off-Gas to FRP } \\
\text { (Includes process upsets) }\end{array}$ \\
\hline Vessel Ventilation & $2 E 5$ & 1, MFP & APS & $\begin{array}{l}\text { Air with small amounts of } \mathrm{NO}_{\mathrm{x}} \\
\text { and } \mathrm{HNO}_{3}\end{array}$ \\
\hline Cell Ventilation & $1.2 \mathrm{~EB}$ & 2. MFP & APS & $\begin{array}{l}\text { Air with trace particulates, } \mathrm{NO}_{x} \\
\text { and } \mathrm{HNO}_{3}\end{array}$ \\
\hline \multicolumn{5}{|l|}{ Solids } \\
\hline Failed Equipment & 50 & 2E4, MFP & Burial & Mostly stainless steel \\
\hline Trash & 100 & 500, MFP & Burial & $\begin{array}{l}\text { Paper, plastics, cloth, metal, glass } \\
\text { and chemicals }\end{array}$ \\
\hline \multicolumn{5}{|l|}{ NONRADIOACTIVE } \\
\hline \multicolumn{5}{|l|}{ Liquids } \\
\hline Processing Cooling Water & $2.1 E 5$ & Negligible & $\begin{array}{l}\text { Environment } \\
\text { or Recycle }\end{array}$ & Warm Water \\
\hline $\begin{array}{l}\text { Cleaning Solutions and Chemical } \\
\text { Wastes (Chemical Sewer) }\end{array}$ & $1 \mathrm{E3}$ & Negligible & Tile Field & $\begin{array}{l}\text { Water with detergent, } \mathrm{HNO}_{3}, \mathrm{NaOH} \\
\text { or Complexant }\end{array}$ \\
\hline Sanitary Wastes (Sanitary Sewer) & $6.5 E 3$ & Negligible & Tile Field & $\begin{array}{l}\text { Showers, Toilets, Wash Basins, } \\
\text { Drinking, etc. }\end{array}$ \\
\hline \multicolumn{5}{|l|}{ Gases } \\
\hline $\begin{array}{l}\text { Operating Area Ventilation Air } \\
\text { Warm Area Ventilation Air }\end{array}$ & $\begin{array}{l}\sim 8 \mathrm{E} 7 \\
\sim 1.6 \mathrm{E} 8\end{array}$ & $\begin{array}{l}\text { Negligible } \\
\text { Negligible }\end{array}$ & $\begin{array}{l}\text { Environment } \\
\text { APS }\end{array}$ & $\begin{array}{l}\text { Warm Air, } \leq 80^{\circ} \mathrm{F} \\
\text { Warm Air, } \leq 80^{\circ} \mathrm{F}\end{array}$ \\
\hline \multicolumn{5}{|l|}{ Solids } \\
\hline Failed Equipment & 20 & Negligible & $\begin{array}{l}\text { Sanitary } \\
\text { Landfill }\end{array}$ & Mostly stainless and mild steel \\
\hline Trash & 1000 & Negligible & $\begin{array}{l}\text { Sanitary } \\
\text { Landfill }\end{array}$ & $\begin{array}{l}\text { Paper, plastics, cloth, metal, glass and } \\
\text { chemicals }\end{array}$ \\
\hline HEAT RELEASES & $\mathrm{kW}$, Average & & & \\
\hline Ventilation Air Systems & 300 & & & \\
\hline $\begin{array}{l}\text { Cooling Water } \\
\text { Miscellaneous (includes Building }\end{array}$ & 230 & & & \\
\hline Losses) Total & $\frac{70}{\sim 600}$ & & & \\
\hline
\end{tabular}

(a) MFP = Mixed Fission Products

(b) Ru = Ruthenium

(c) APS = Atmospheric Protection System 

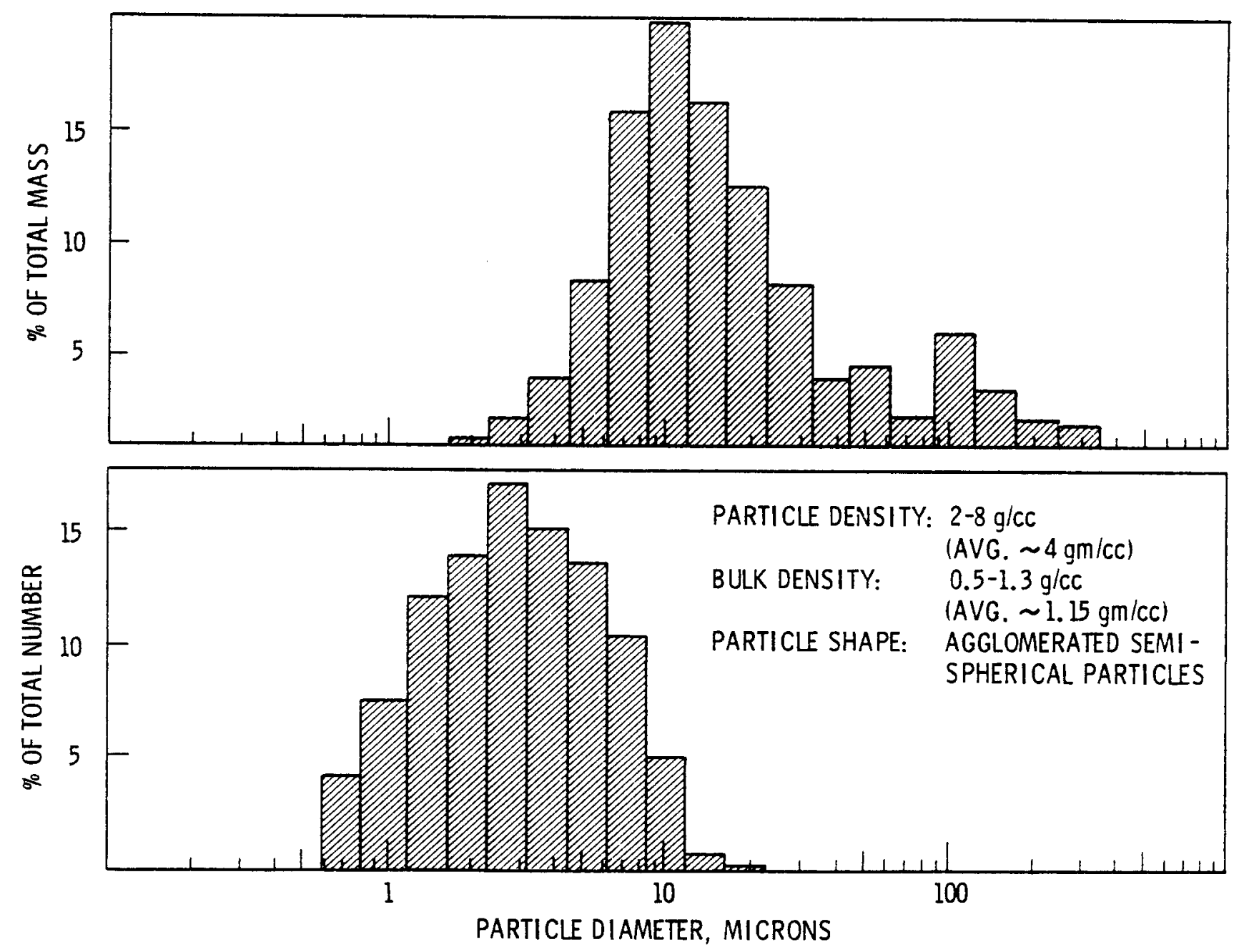

FIGURE 23. Spray Calcine Properties 


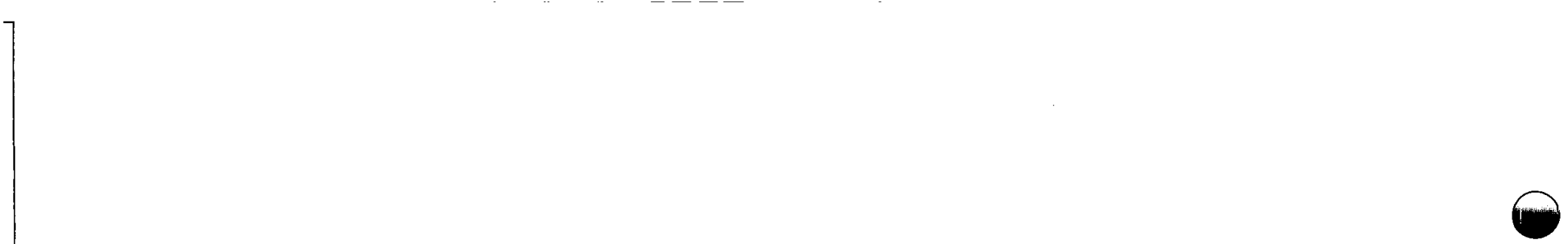
-

(

$\bullet$

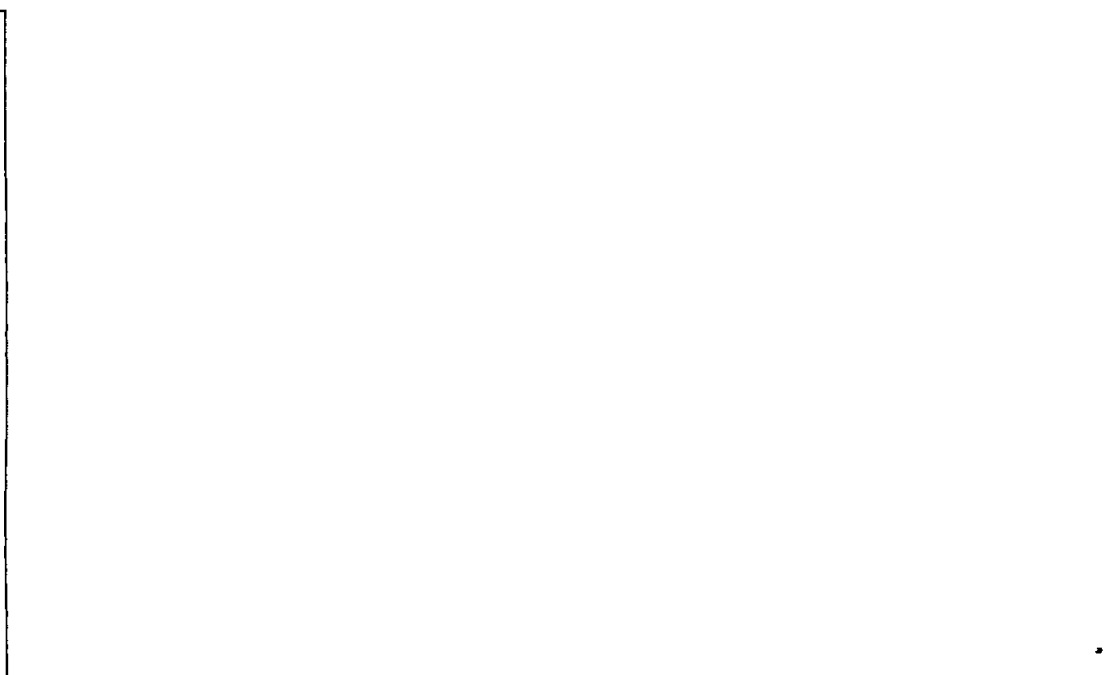




\section{SITING}

The nuclear waste vitrification facility will be constructed as an integral part of a nuclear FRP. Economy and efficiency of integration with other plant operations will determine the location of the NWVF within the plant. Thus, it will have to conform to criteria for the FRP siting. Since the NWVF does not possess unique characteristics as related to the FRP, it will not require additional siting criteria.

The amount of land necessary for dedication to the NWVF will be negligible compared to the amount of land required for the FRP. The vitrification facility, including the waste operating area and other service areas, will occupy a ground space of roughly $460 \mathrm{~m}^{2}\left(5000 \mathrm{ft}^{2}\right)$. 
$\ominus$

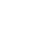




\section{OPERATIONS}

The routine operating sequence will be performed in the facility as outlined below:

- Move up to three empty canisters with lids, into the CDC on a dolly, and then shut the cubicle door to the aisle or tunnel.

- Remove the cubicle cover block and move the canisters with the crane to empty the canister storage rack positions with the crane. Replace the cover block.

- Remove the lid from the canister with the crane hook or manipulator, as the design requires.

- Pick up the melter top with the crane, then raise the empty canister with the melter top yoke and place it in the melter.

- Move the melter with the empty canister into position under the calciner with the melter umbilical pipe.

- Connect the melter to the calciner using electro-pneumatic devices.

- Heat the canister to the melting temperature.

- When the canister in the companion melter is filled, move the calciner diverter valve to fill the heated canister.

- As the melt level rises in the canister, discontinue heating and start cooling below the melt level to prevent excessive system temperatures.

- When the canister is full, allow it to sit at operating temperature for several hours to allow final glass melting and out-gassing.

- Disconnect the canister, and move it from under the calciner.

- Place a prepared helium source in the canister with manipulator (or the source may be attached to the canister lid). Then place the lid on the canister using the crane or manipulator, as designed.

- Move the canister to the WIS.

- Place canister in position under the remote welding head and seal weld. 
- Move the canister into position under the remote helium leak test head and check the canister seal weld for leaks.

- Move the filled canister with the crane to a full-canister position in the CSR where it is maintained at a desirable temperature.

- As appropriate, move the filled canisters by crane through the hatch onto the dolly in the CDC and replace the hatch cover.

- Decontaminate the full canister or canisters in the dolly with medium pressure steam or decontamination solution passed through spray nozzles mounted on the cubicle walls.

- After allowing the canistar to dry, move it by dolly through the door for transfer to interim storage in the FRP.

There are also other periodic operations that will be performed.

These include:

- removing calciner condensate from the calciner condensate tank (CCT) to the HLLW concentrator feed tank,

- changing decontamination solution in the DST and routing the expended solution to the HLLW concentrator feed tank,

- jetting the sump solutions to a waste collection tank for sampling,

- regenerating the ruthenium sorber with dilute nitric acid or hot water and routing strip solution to the HLLW concentrator feed tank,

- flushing equipment for decontamination and routing the decontamination solution to the HLLW concentrator feed tank,

- repairing occasional seal weld leaks or overpacking a breached canister, and

- flushing a calciner seal pot to the HLLW concentrator feed tank and filling it with water.

Other NWVF operations are described in the "Process Description" or are maintenance activities.

The staffing requirements to operate this facility are shown in Table 11. This table shows full-time operating personnel and indicates the 
TABLE 11. Allocated Facility Staffing Requirements (a) Job Description \begin{tabular}{l} 
Number \\
of Staff \\
\hline
\end{tabular}

Operations

Process Operators

11

Radiation Monitors

Supervisors

Managers

others

0.25

4

Maintenance and Services (Plant Forces)

Craft Workers

Planners and Supervisors

5

Managers

0.25

others

4

Technical

Process Engineers

1

Facility Engineers

1

Safety

1

Technicians

3

Managers

0.5

Others (Including Analytical)

4

Administrative

others

Totals: Nonexempt 31

Exempt 7

Supervisors 3

Managers 1

42

(a) Assume NWVF is integrated with other FRP operations. 
equivalent personnel that would spend part of their time associated with the facility. Except for an instrument technician, a pipefitter, a millwright, and a welder, who would be on shift to perform minor equipment upkeep duties, maintenance personnel are excluded from the table.

As indicated previously, the NWVF will be incorporated into the reprocessing plant structure. It is not anticipated that it will add any noticeable incremental noise, visual presence, or other undesirable features to the site or local population. A very small amount of $\mathrm{NO}_{\mathrm{x}}$ and $\mathrm{NH}_{3}$ will be added to the FRP stack air. It is not anticipated that the local population will notice these incremental gases. 


\section{MAINTENANCE}

The vitrification equipment is designed for total remote operation with minimum aid of master-slave or electro-mechanical manipulators. Supporting equipment that requires contact maintenance, such as the frit feeder, welder and the mass spectrometer, will be located out-of-cell. Appropriate air locks, anti-backflow devices, and block valves will be provided between the in-cell and out-of-cell equipment to ensure safe operation.

To keep personnel exposure low, all major in-cell equipment pieces are designed for remote replacement. In addition, components that may wear out or fail can be remotely replaced without removing the major equipment. Lifting lugs on the equipment will facilitate remote handling with the in-cell crane. Alignment dowels and fixed mounting trunions will be used to ensure exact positioning of equipment and components. For the most part only the in-cell crane and an impact wrench will be required for remote maintenance, although master-slave manipulators will be provided at locations where they could be required. Hanford-type piping and electrical connectors will be used for most service and process connections. Hanfordtype remote tank flanges will also be used to install pumps, agitators, and filter assemblies. Vee flanges and other quick connective devices will be used where Hanford-type connections are not appropriate. Certain highmaintenance items will be located in shielded wall niches. These items include the spray calciner filter blowback valves and frit feeder air lock valves which, al though normally nonradioactive, could become contaminated. Contact maintenance will also be employed on all out-of-cell supporting equipment.

Equipment will be moved into or out of the cell through the shielding doors to the hot maintenance area (HMA). When the door is open, air will flow from the HMA into the cell at a rate that minimizes the escape of radioactivity from the cell. Equipment will be internally and externally decontaminated prior to removal from the cell. The equipment may be maintained in the HMA, if desired and the radiation level is sufficiently low, or the equipment may be placed in a shielded container for storage. The 
crane will also be maintained in the HMA. Should the crane become immobilized in the cell a small remote service crane or another crane on the same rail may be used to retrieve it.

Special precautions will be observed in removing and replacing equipment which penetrates the cell wall, such as the shielding windows, melter umbilical pipe, manipulators, and periscope. Special procedures will be required to ensure minimal exposure to maintenance personnel and to prevent the spread of radioactive contamination to cold or warm areas. 


\section{REFERENCES}

1. H. T. Blair, Vitrification of Nuclear Waste Calcines by In-Can Melting, BNWL-2061, Battel 1e, Pacific Northwest Laboratory, Richland, WA, May 1976.

2. W. F. Bonner, H. T. Blair and L. S. Romero, Spray Solidification of Nuclear Waste, BNWL-2059, Battelle, Pacific Northwest Laboratory, Richland, WA, August 1976.

3 Edited by D. E. Larson and W. F. Bonner, High-Level Waste Vitrification by Spray Calcination/In-Can Melting, BNWL-2092, Battelle, Pacific Northwest Laboratory, Richiand, WA, November 1976.

4 J. L. McElroy et al., Waste Solidification Summary Report, Volume 11 , Evaluation of High Level Waste Solidification Processes, BNWL-1667, Battelle, Pacific Northwest Laboratory, Richland, WA, July 1972.

5 W. R. Bond et al., Waste Solidification Program, Volume 6, Spray Solidification Performance During the First Radioactive Tests in Waste Solidification Engineering Prototypes, BNWL-1391, Battelle, Pacific Northwest Laboratory, Richland, WA, August 1976.

6 W. R. Bond et al., Waste Solidification Program, Volume 8, Spray Solidification Performance During Final Radioactive Tests in the waste Solidification Engineering Prototypes, BNWL-1583, Battel1e, Pacific Northwest Laboratory, Richland, WA, June 1971.

7 K. J. Schneider and V. P. Kelly, Waste Solidification Program, Volume II, Design Features of the Waste Solidification Engineering Prototypes, BNWL-168, Battelle, Pacific Northwest Laboratory, Richland, WA, February 1969.

8 Code of Federal Regulations, Title 10. Published by the Office of the Federal Register-National Archives and Records Service-General Services Administration, Revised as of January \}, 1976. 
•

8

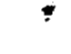




\section{DISTRIBUTION}

No. of

Copies

OFFSITE

A. A. Churm

DOE Chicago Patent Division

9800 South Cass Avenue

Argonne, IL 60439

R. E. Cunningham

Deputy Director for Fuels and Materials

Nuclear Regulatory Commission

Silver Springs, MD 20910

Assistant Director for Radioactive Waste Management Branch

NRC Division of Materials and Fuel Cycle Facility Licensing

Washington, DC 20545

W. G. Belter

DOE Division of Biomedical and Environmental Research

Earth Sciences Branch

Washington, DC 20545

W. A. Brobst

DOE Division of Environmental Control Technology

Washington, DC 20545

W. E. Mott

DOE Division of Environmental Control Technology

Washington, DC 20545

R. B. Chitwood

DOE Division of Nuclear Power Development

Washington, DC 20545

T. C. Chee

DOE Office of Nuclear Waste

Management

Washington, DC 20545
No. of

Copies

C. R. Cooley

DOE Office of Nuclear Waste

Management

Washington, DC 20545

Sheldon Meyer

DOE Office of Nuclear Waste Management

Washington, DC 20545

R. G. Romatowski

DOE Office of Nuclear Waste Management

Washington, DC 20545

C. W. Kuhlman

DOE Office of Nuclear Waste Management

Washington, DC 20545

C. A. Heath

DOE Office of Nuclear Waste Management

Washington, DC 20545

G. Oertel

DOE Office of Nuclear Waste

Management

Washington, DC 20545

A. F. Perge

DOE Office of Nuclear Waste Management

Washington, DC 20545

W. S. Scheib, Jr.

DOE Office of Nuclear Waste

Management

Washington, DC 20545

D. L. Vieth

DOE Office of Nuclear Waste

Management

Washington, DC 20545 
R. D. Walton

DOE Office of Nuclear Waste

Management

Washington, DC 20545

J. Neff, Program Manager

Department of Energy

Columbus Program Office

505 King Avenue

Columbus, $\mathrm{OH} 43201$

J. B. Whitsett

DOE Idaho Operations Office

P.0. Box 2108

Idaho Falls, ID 83401

J. J. Schreiber

DOE Oak Ridge Operations Office

P.0. Box X

Oak Ridge, TN 37830

John Van Cleve

DOE Oak Ridge Operations Office

P.0. Box $X$

Oak Ridge, TN 37830

E. S. Goldberg

DOE Savannah River Operations Office

P.0. Box A

Aiken, SC 29801

27 DOE Technical Information Center

A. P. Roeh, Manager

Allied Chemical Corporation

550 2nd Street

Idaho Falls, ID 83401

J. R. Berreth

A1lied Chemical Corporation

550 2nd Street

Idaho Fal1s, ID 83401

Allied Chemical Corporation (File Copy)

550 2nd Street

Idaho Falls, ID 83401
M. D. McCormack

E.G.\&G. Idaho, Inc.

P.0. Box 1625

Idaho Falls, ID 83401

W. C. Seymour

E.G.\&G. Idaho, Inc.

P.0. Box 1625

Idaho Falls, ID 83401

R. A. Buckham

Allied-General Nuclear Service

P.0. Box 847

Barnwel1, SC 29812

A. Williams

Allied-General Nuclear Service

P.0. Box 847

Barnwel1, SC 29812

J. L. Jardine

Argonne National Laboratory

9700 South Cass Avenue

Argonne, IL 60439

M. M. Steindler

Argonne National Laboratory

9700 South Cass Avenue

Argonne, IL 60439

L. E. Trevorrow

Argonne National Laboratory 9700 South Cass Avenue

Argonne, IL 60439

J. M. Batch

Battelle Memorial Institute

505 King Avenue

Columbus, $\mathrm{OH} 43201$

Wayne Carbiener

Battelle Memorial Institute

505 King Avenue

Columbus, $\mathrm{OH} 43201$

J. D. Duguid

Battelle Memorial Institute

505 King Avenue

Columbus, $\mathrm{OH} 43201$ 
No. of

Copies

R. E. Heineman

Battelle Memorial Institute

505 King Avenue

Columbus, $\mathrm{OH} 43201$

Brookhaven National Laboratory

Reference Section

Information Division

Upton, NY 11973

\section{Steinberg}

Brookhaven National Laboratory

Upton, NY 11973

Combustion Division

Combustion Engineering, Inc.

Windsor, CT 06095

B. Adams

Corning Glass Works

Technical Staffs Division

Corning, NY 14830

E. Vejvoda, Director

Chemical Operations

Rockwell International

Rocky Flats Plant

P.0. Box 464

Golden, CO 80401

J. L. Crandall

E. I. Du Pont de Nemours and Company

Savannah River Laboratory

Aiken, SC 29801

H. L. HuTl

E. I. Du Pont de Nemours and Company

Savannah River Laboratory

Aiken, SC 29801

H. Henning

Electric Power Research. Institute

$3412 \mathrm{Hillview} \mathrm{Avenue}$

P.O. Box 10412

Palo Alto, CA 94301
No. of

Copies

Environmental Protection Agency

Technology Assessment Division

(AW-559)

Office of Radiation Programs

Washington, DC 20460

R. G. Barnes

General Electric Company

175 Curtner Avenue (M/C 160)

San Jose, CA 95125

L. H. Brooks

Gulf Energy and Environmenta] Systems

P.0. Box 81608

San Diego, CA 92138

E. S. Goldberg

Savannah River Operations Office P.0. Box A

Aiken, SC 29801

D. C. Fulmer

Savannah River Operations Office P.O. Box A

Aiken, SC 29801

Los Alamos Scientific Laboratory (DOE)

P.O. Box 1663

Los Alamos, NM 87544

C. J. Kershner

Monsanto Research Corporation

Mound Laboratory

P.0. Box 32

Miamisburg, $\mathrm{OH} 45342$

John Pomeroy

Technical Secretary

National Academy of Sciences

Committee of Radioactive Waste Management

National Research Council

2101 Constitution Avenue

Washington, DC 20418 
No. of

Copies

S. D. Barrett

New England Power Company

280 Melrose Street

Providence, RI 02901

J. P. Duckworth

Plant Manager

Nuclear Fuel Services, Inc.

P.0. Box 124

West Valley, NY 14171

J. G. Cline, General Manager

NYS Energy Research and Development Authority

230 Park Avenue, Rm 2425

New York, NY 10017

2 Oak Ridge National Laboratory (DOE)

Central Research Library

Document Reference Section

P.0. Box X

Oak Ridge, TN 37830

E. H. Kobish

Solid State Division

Oak Ridge National Laboratory

Oak Ridge, TN 37830

G. J. McCarthy

Pennsylvania State University

Materials Research Laboratory

University Park, PA 16802

D. R. Anderson

Sandia Laboratories

Albuquerque, NM 87107

W. Weart

Sandia Laboratories

Albuquerque, NM 87107

J. 0. Blomeke

Union Carbide Corporation (ORNL)

Chemical Technology Division

P.0. Box $Y$

Oak Ridge, TN 37830
No. of

Copies

2 D. E. Ferguson

Union Carbide Corporation (ORNL)

Chemical Technology Division

P.0. Box $Y$

Oak Ridge, TN 37830

H. W. Godbee

Union Carbide Corporation (ORNL)

Chemical Technology Division

P.0. Box $Y$

Oak Ridge, TN 37830

W. C. McClain

Union Carbide Corporation (ORNL)

Chemical Technology Division

P.0. Box Y

Oak Ridge, TN 37830

R. A. Beall

U. S. Department of Interior Bureau of Mines

Albany Research Center

1450 W. Queen Avenue

Albany, OR 97321

D. B. Stewart

U. S. Department of Interior

959 National Center

Geological Survey

Reston, VA 22092

R. G. Post

College of Engineering

University of Arizona

Tucson, AZ 85721

S. E. Logan

Los Alamos Technical

Associates, Inc.

P.0. Box 410

Los Alamos, NM 87544

DNSITE

3 DOE Richland Operations Office

H. E. Ransom

M. W. Shupe

M. J. Zamorski 
No. of

Copies

5 Rockwe 11 Hanford Operations

H. Badad

R. A. Deju

R. J. Gimera

D. D. Wodrich

File Copy

Exxon Nuclear Company

S. J. Beard

Joint Center for Graduate Study

J. Cooper

United Nuclear Industries, Inc.

T. E. Dabrowski

Westinghouse Hanford Company

A. G. Blasewitz

G. L. Richardson

39 Pacific Northwest Laboratory

T. W. Ambrose

W. J. Bjorklund

H. T. Blair

W. F. Bonner

D. J. Bradley

A. Brandstetter

T. D. Chikalla

C. M. Hagen

y. S. Hanson

Y. B. Katayama

D. E. Knowiton

L. T. Lakey

D. E. Larson (3)

J. M. Lukacs

R. P. Marsha 11

J. L. McElroy

R. W. McKee

G. B. Mellinger

J. E. Mendel

R. E. Nightingale

J. H. Jarrett
No. of

Copies

D. E. Olesen

A. M. Platt

D. L. Prezbindowski

L. S. Romero

W. A. Ross

J. M. Rusin

D. H. Siemens

S. C. Slate

R. T. Treat

R. P. Turcotte

H. H. Van Tuyl

L. D. Williams

W. K. Winegardner

Technical Information (5)

Publishing Coordination (2) 